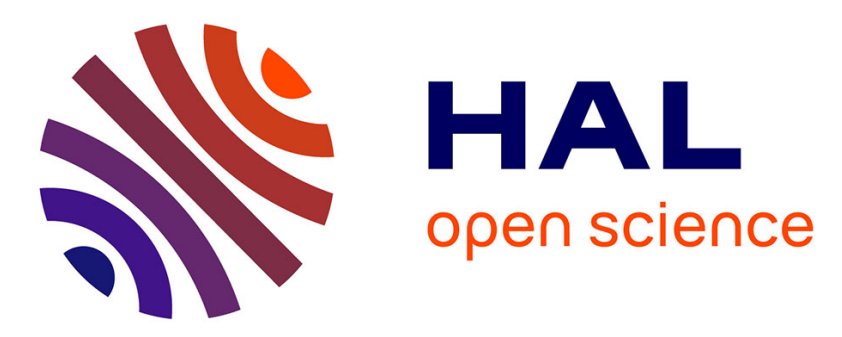

\title{
High performance cork-templated ceria for solar thermochemical hydrogen production via two-step water-splitting cycles
}

Fernando Costa Oliveira, M. Alexandra Barreiros, Anita Haeussler, Ana Caetano, Ana Mouquinho, Pedro Oliveira E Silva, Rui Novais, Robert Pullar, Stéphane Abanades

\section{To cite this version:}

Fernando Costa Oliveira, M. Alexandra Barreiros, Anita Haeussler, Ana Caetano, Ana Mouquinho, et al.. High performance cork-templated ceria for solar thermochemical hydrogen production via two-step water-splitting cycles. Sustainable Energy \& Fuels, 2020, 4, pp.3077-3089. 10.1039/D0SE00318B . hal-02566065

\section{HAL Id: hal-02566065 https://hal.science/hal-02566065}

Submitted on 5 Nov 2020

HAL is a multi-disciplinary open access archive for the deposit and dissemination of scientific research documents, whether they are published or not. The documents may come from teaching and research institutions in France or abroad, or from public or private research centers.
L'archive ouverte pluridisciplinaire HAL, est destinée au dépôt et à la diffusion de documents scientifiques de niveau recherche, publiés ou non, émanant des établissements d'enseignement et de recherche français ou étrangers, des laboratoires publics ou privés. 


\title{
High performance cork-templated ceria for solar thermochemical hydrogen production via two-step water-splitting cycles
}

Fernando A. Costa Oliveira, ${ }^{\mathrm{a}}$ M. Alexandra Barreiros, ${ }^{\mathrm{a}}$ Anita Haeussler, ${ }^{\mathrm{b}}$ Ana P.F. Caetano, ${ }^{\mathrm{c}}$ Ana I. Mouquinho, ${ }^{a}$ Pedro M. Oliveira e Silva, ${ }^{\text {a }}$ Rui M. Novais, ${ }^{\mathrm{c}}$ Robert C. Pullar* and Stéphane Abanades ${ }^{\mathrm{b}}$

${ }^{\text {a }}$ LNEG - Laboratório Nacional de Energia e Geologia I.P., LEN - Laboratório de Energia, Materials for Energy Unit, Estrada do Paço do Lumiar 22, 1649-038 Lisboa, Portugal

${ }^{b}$ Processes, Materials, and Solar Energy Laboratory (PROMES-CNRS), 7 Rue du Four Solaire, 66120 Font-Romeu, France

${ }^{c}$ University of Aveiro, Department of Materials and Ceramic Engineering/CICECO - Aveiro Institute of Materials, Campus Universitário de Santiago, 3810-193 Aveiro, Portugal

* Corresponding authors: fernando.oliveira@Ineg.pt (F.A.C. Oliveira); rpullar@ua.pt (R.C. Pullar)

\begin{abstract}
Water splitting by solar energy-driven two-step thermochemical cycles is a promising approach for large-scale production of renewable fuels (e.g. hydrogen). The key challenge is developing materials capable of withstanding the harsh environmental conditions and to ensure high reliability in use, particularly in terms of redox kinetics and better activity at low operation temperatures. In this work, we demonstrate that cork-templated ceria can significantly enhance the hydrogen production performance under solar irradiation heating. Three types of ceria morphologies were synthesised and investigated in two-step thermochemical redox cycles, namely ceria granules (ecoceramics) prepared from cork templates based on either a green water-based or an acetone solvent-based approach, as well as ceria foams replicated from polyurethane templates. These materials were cycled in a high-temperature indirectly-irradiated solar tubular reactor, heated via concentrated solar light, using a temperature-swing process. Samples were typically thermally reduced at $1400-1450{ }^{\circ} \mathrm{C}$ and subsequently re-oxidised with $\mathrm{H}_{2} \mathrm{O}$ between $950-1150{ }^{\circ} \mathrm{C}$. The green synthesis ceria granules had up to $25 \%$ and $32 \%$ higher average $\mathrm{H}_{2}$ production yields than the acetone-based ecoceramics and replicated ceria foams, respectively. On average, $\mathrm{H}_{2}$ production rates for cork-templated ceria granules $\left(1.3 \pm 0.2 \mathrm{~mL} \mathrm{~min}^{-1} \mathrm{~g}^{-1}\right)$ were up to $60 \%$ higher than for ceria foams $\left(0.8 \pm 0.3 \mathrm{~mL} \mathrm{~min}^{-1} \mathrm{~g}^{-1}\right)$, indicating that the morphology of this
\end{abstract}


three-dimensionally ordered macroporous (3-DOM) $\mathrm{CeO}_{2}$ improves the reaction kinetics. This is attributed to the smaller mean cell size of the cork-derived ecoceramic $(25 \mu \mathrm{m})$ compared to that of the replicated ceria foam $(575 \mu \mathrm{m})$, suggesting that their semi-closed wall cells enhanced reaction rates. The increase in reduction temperature from 1400 to $1450{ }^{\circ} \mathrm{C}$ resulted in the highest $\mathrm{H}_{2}$ production rate $\left(1.6 \mathrm{~mL} \mathrm{~min}^{-1} \mathrm{~g}^{-1}\right)$ reported so far for 3DOM ceria. Neither loss in redox performance nor change in grain morphology was observed from the first to the last cycle. These findings show that cork-like structural features are key to engineering efficient materials for enhanced solar thermochemical fuel production.

\section{Keywords}

$\mathrm{H}_{2} \mathrm{O}$ splitting; Hydrogen; Ceria; Solar fuels; Thermochemical cycle; Cork; Solar reactor.

\section{Introduction}

Sustainable growth while protecting Earth's environment is one of the most important challenges facing humankind today. Global energy demand will continue to rise due to the continuous population growth and industrialisation expansion. Major concerns with climate change related to the use of fossil fuels make urgent the need to diversify energy sources away from fossil fuels by switching to renewable sources, such as solar, wind and hydropower. In this respect, hydrogen from water splitting has received considerable attention as a sustainable energy fuel. Hydrogen, as a viable alternative fuel, still remains a thorny and challenging issue, hindered by a lack of motivation, interest and investment.

Currently, hydrogen is mostly generated from fossil fuels.1 Besides reforming, hydrogen can be produced from solid bioresources 2 and from water.3 Electrolysis of water is promising as electricity supplied from solar energy can be stored as hydrogen (power to gas).4 Another compelling approach is the conversion of solar energy into $\mathrm{H}_{2}$ via two-step thermochemical cycles driven by concentrated solar thermal heat, using reducible metal oxides. $^{5,6,7,8}$ A comprehensive review of the applications and limitations of two step metal oxide thermochemical redox cycles highlighted the benefits of using such cycles to split $\mathrm{H}_{2} \mathrm{O}$ and $\mathrm{CO}_{2}$, offering a high-potential route to renewable fuel production.9 By using a redox pair such as $\mathrm{SnO}_{2} / \mathrm{SnO}, \mathrm{ZnO} / \mathrm{Zn}, \mathrm{Fe}_{3} \mathrm{O}_{4} / \mathrm{FeO}$, or $\mathrm{CeO}_{2} / \mathrm{Ce}_{2} \mathrm{O}_{3}$, as well as non-stoichiometric materials, such as ceria $\left(\mathrm{CeO}_{2-\delta}\right)^{10}$ and perovskite oxides $\left(\mathrm{ABO}_{3-\delta}\right){ }^{11}$ the water splitting 
reaction can be performed in two steps: an endothermic step at high temperature $\left(\sim 1200-2000{ }^{\circ} \mathrm{C}\right)$, in which the oxide is reduced in inert atmosphere, and a subsequent exothermic step at lower temperature, in which water oxidises the metal oxide producing $\mathrm{H}_{2}$ (at $\sim 400-1200{ }^{\circ} \mathrm{C}$ ). The working temperature of each step, $\mathrm{O}_{2}$ and $\mathrm{H}_{2}$ yields, and the fuel production rate depend strongly on the type and form of metal oxide involved.

For tin and zinc oxide cycles, the products ( $\mathrm{SnO}$ and $\mathrm{Zn}$ ) are both in a gaseous state during the reduction step, which complicates the recovery of the reduced material owing to recombination issues in the gas phase. Both iron and cerium-based oxides, however, remain in the condensed state during cycling, making them easier to implement in a solar process.

Compared with nonstoichiometric oxides such as ceria, ferrites have a much greater reduction capacity at a given temperature, as proposed by Nakamura. ${ }^{12}$ Although $\mathrm{Fe}_{3} \mathrm{O}_{4}$ releases $\mathrm{O}_{2}$ to form the $\mathrm{Fe}_{1-\mathrm{y}} \mathrm{O}$ phases prior to forming a liquid slag, the reduction is not complete until temperatures are above the melting point of the $\mathrm{FeO}$ phase $\left(1377^{\circ} \mathrm{C}\right)$. The formation of a liquid phase leads to sintering and gas-transport limitations that hinder the oxidation reaction to unacceptable rates, which presents serious challenges for practical implementation. ${ }^{13}$ This issue can be addressed by decreasing the temperature required for reduction via substitution of up to $50 \%$ of the $\mathrm{Fe}(\mathrm{II})$ cations with a divalent metal, such as $\mathrm{Mn}$, Co or Ni, which simultaneously raises the melting point. ${ }^{14}$ However, only relatively small amounts of hydrogen were generated in the water-splitting step, owing to either limited nonstoichiometry or deactivation of the redox material at high temperatures.

Another approach is to use ceria or $\mathrm{CeO}_{2}$ - transition metal oxide solid solutions, thanks to their stability at high temperature for the $\mathrm{O}_{2}$ releasing reaction. Indeed, the formation of solid solutions between $\mathrm{MO}_{\mathrm{x}}(\mathrm{M}=\mathrm{Mn}, \mathrm{Fe}$ or $\mathrm{Ni})$ and $\mathrm{CeO}_{2}$ enhanced the ability of the twostep water splitting reaction at lower temperatures compared to $\mathrm{CeO}_{2}$, on account of the superior formation of $\mathrm{O}_{2}$ vacancies in the solid solution of $\mathrm{CeO}_{2}-\mathrm{MO}_{\mathrm{x}} \cdot{ }^{15}$ In particular, $\mathrm{CeO}_{2}-x \mathrm{Fe}_{2} \mathrm{O}_{3}(\mathrm{x}=0.026-0.214)$ solid solutions were found to produce $1.9 \mathrm{~mL} \mathrm{H} / \mathrm{g}$, after reduction at $1400{ }^{\circ} \mathrm{C}$ followed by oxidation with steam at $1000{ }^{\circ} \mathrm{C}$, without any significant loss of $\mathrm{H}_{2}$ yield, thereby confirming their thermal stability. ${ }^{16}$ The enhanced mobility of $\mathrm{O}^{2-}$ ions via oxygen vacancies with the presence of $\mathrm{Fe}^{2+}$ and $\mathrm{Fe}^{3+}$ in $\mathrm{CeO}_{2}-x \mathrm{Fe}_{2} \mathrm{O}_{3}$ solid solution is presumed to promote $\mathrm{O}_{2}$ release at $1400{ }^{\circ} \mathrm{C}$, and consequently the amount of $\mathrm{H}_{2}$ evolved at $1000^{\circ} \mathrm{C}$.

The use of ceria-based materials has, therefore, been investigated because $\mathrm{CeO}_{2}$ 
undergoes partial reversible reduction between the $\mathrm{Ce}^{3+}$ and $\mathrm{Ce}^{4+}$ oxidation states, and it contains many oxygen vacancies within its structure, which is essential for improving oxygen mobility. ${ }^{17}$

Decomposition of water by a partially reduced $\delta$-phase of cerium oxide $\left(\mathrm{CeO}_{1.818}\right)$ was reported to occur at $\geq 25^{\circ} \mathrm{C} .{ }^{18}$ Recently, ceria has attracted great deal of attention, since it is one of the most promising materials being applied in two-step water-splitting cycles. The solar-driven water splitting process utilising ceria was first demonstrated at lab-scale by Abanades and Flamant. ${ }^{19}$ They showed that reduction of $\mathrm{Ce}^{4+}$ to $\mathrm{Ce}^{3+}$ is highly temperature dependent, and complete reduction to $\mathrm{Ce}_{2} \mathrm{O}_{3}$ could only be achieved in argon at 100-200 mbar during melting above $2000^{\circ} \mathrm{C} . \mathrm{Ce}_{2} \mathrm{O}_{3}$ shows a very good reactivity with water and the $\mathrm{H}_{2}$ production yield is $2.9 \mathrm{mmol} \mathrm{H}_{2} / \mathrm{g}$ of $\mathrm{CeO}_{2}\left(65 \mathrm{~mL} \mathrm{H}_{2} / \mathrm{g}\right)$. This cycle, however, suffers from a partial sublimation of ceria at the reduction temperature, which decreases the reduction yield. Moreover, such temperatures result in considerable radiation heat losses and possible quickened ageing of reactor construction materials. Therefore, the decrease of the reduction temperature to $1400-1500{ }^{\circ} \mathrm{C}$ is preferable from a practical viewpoint. At lower temperatures, ceria cannot be fully reduced, and $\mathrm{H}_{2}$ production depends on the degree of reduction achieved $(\delta)$. The non-stoichiometry $\delta$ determines the fuel production yield, and it is a function of both temperature and oxygen partial pressure. In addition, ceria retains its cubic fluorite structure when reduced to nonstoichiometries of $\delta$ up to $0.286,{ }^{20}$ which thereby avoids extensive sintering and ceria sublimation (particularly evident above 1800 $\left.{ }^{\circ} \mathrm{C}\right)$. The current state-of the-art on the advancements of solar thermochemical cycles performed with cerium-based oxides was recently reviewed. ${ }^{21}$ In terms of material properties, the main drawback of ceria is its greater difficulty in reduction, which thus limits the overall fuel productivity. Typically, less than $5 \%$ of oxygen atoms per cerium atom are removed from the crystal structure during the reduction at $1400^{\circ} \mathrm{C}$ and $p_{\mathrm{O}_{2}}$ of $10^{-5} \mathrm{~atm}$.

Whereas thermodynamics governs the theoretically achievable fuel productivity, that is, the fuel produced per cycle, the rate at which fuel is produced is a function of kinetics.

While the thermodynamic properties of ceria are known, the oxidation kinetics of nonstoichiometric ceria depends greatly on the material morphology and microstructure. ${ }^{22}$ Although the degree of ceria reduction is favoured at high temperatures and low oxygen activities, other factors affecting reduction of ceria include heating rate, ceria morphology, 
and dopants addition. In addition, ceria with morphologies that retain high specific surface area and interconnected micron-scale porosity allow for more rapid fuel production, as highlighted in a comprehensive review on the effect of designed morphologies and microstructures of ceria-based ceramics on the solar thermochemical $\mathrm{CO}_{2}$ splitting process. $^{23}$ Three-dimensionally ordered macroporous (3-DOM) ceria, featuring both interconnected and ordered pores, was reported to increase the $\mathrm{H}_{2}$ and $\mathrm{CO}$ production yields by $75 \%$ and $175 \%$, respectively. ${ }^{24}$ This was attributed to its enhanced surface area and its interconnected pore structure that facilitates the transport of reacting species to and from oxidation sites. Such macroporous structures also affect the radiative properties of ceria ceramics, resulting in an increase of the transport scattering coefficient that permits longer attenuation path lengths of the incident concentrated solar beam, thereby favouring radiation absorption during thermochemical cycling. ${ }^{25}$ In addition, pore size, for a porosity of 0.90 , was found to play a crucial role on the permeability, extinction coefficient and optical thickness of a porous medium, thereby affecting the transport properties and redox chemistry. $^{26}$

Although various doping strategies for ceria have been extensively studied, additions of either $\mathrm{Zr}$ or $\mathrm{Hf}$ have been proven to be particularly effective in improving the reduction extent. ${ }^{27}$ However, they adversely affect the oxidation properties, which results in slower oxidation rates and in overall low fuel production performance as compared to pure $\mathrm{CeO}_{2}{ }^{28}$ Addition of $\mathrm{V}$ (up to $25 \%$ ) was also found to enhance syngas production from $\mathrm{CO}_{2}$ and $\mathrm{H}_{2} \mathrm{O}$ splitting coupled to methane partial oxidation owing to the fact that $\mathrm{CeVO}_{4}$ facilitates carbide oxidation, thereby decreasing the extent of methane cracking. ${ }^{29}$ Moreover, a similar trend was observed for 3 at\% Ce-doped $\mathrm{Mn}_{3} \mathrm{O}_{4}$ during methane partial oxidation and $\mathrm{CO}_{2}$ splitting at $1173 \mathrm{~K}$ for the production of syngas. ${ }^{30}$

The reduction of ceria also critically depends on the oxygen partial pressure. In this respect, purging the reactor with a sweep of inert gas is a simple way for reducing the oxygen partial pressure (adopted in the present study). Another possibility is the reduction of the total pressure by vacuum pumping. ${ }^{31}$ The use of thermochemical pumps seems to be far more efficient than mechanical pumps, especially for pressures below 1 mbar. ${ }^{32}$ However, the removal of oxygen can result in a significant energy penalty for the process. Making such technology practical and cost-effective poses appreciable engineering challenges. 
In a previous work, we have demonstrated that ceria granules prepared from cork templates (CG) were effective in solar thermochemical $\mathrm{CO}_{2}$ splitting. ${ }^{33}$ Indeed, the maximum fuel production rate of CG was found to be roughly three times greater than that reported previously for ceria reticulated porous foams with dual-scale porosity. ${ }^{34}$

Cork is the bark of a Mediterranean evergreen oak tree (Quercus suber L.) with a very porous 3-DOM microstructure, consisting of elongated hexagonal closed cells circa $20 \mu \mathrm{m}$ in diameter and $40-50 \mu \mathrm{m}$ long (smaller than most engineering foams), made up of walls having only around $1 \mu \mathrm{m}$ in thickness. This results in lightweight and regular microstructure, with up to 200 million cells per $\mathrm{cm}^{3}, 35$ and a very low density of $120-240 \mathrm{~kg} \mathrm{~m}^{-3}$. Accordingly, cork waste is regarded as an ideal sustainable resource on which to base a material for the production of renewable fuels.

To our best knowledge, no data is available on the performance of ceria-based ecoceramics developed from cork substrates for $\mathrm{H}_{2}$ production. In addition, the performance evaluation of reactive ceria structures in solar reactors under real solar irradiation conditions has scarcely been addressed so far.

In this work, we report on the synthesis of a novel form of sustainable biomimetic material - an ecoceramic produced from a cork template with the unique, highly porous cellular microstructure of cork - made of pure $\mathrm{CeO}_{2}$. This material was used for $\mathrm{H}_{2}$ production in an indirectly irradiated tubular solar reactor via concentrated solar heating through two-step water-splitting cycles. For comparison purposes, ceria foams manufactured by the replication method from polyurethane templates were also evaluated. Our results provide new insights into ceria reactivity that are regarded as useful baseline knowledge for the development of novel materials, and the design of a new generation of concentrated solar fuel reactors.

\section{Experimental Section}

\subsection{Materials preparation}

Two types of ceria-based materials synthesised at both the University of Aveiro and LNEG were investigated, in the form of cork-derived ecoceramic granules, and polymer replicated foams. For this purpose, cork-derived ceria granules were synthesised following a procedure described in Figure 1, in which cork granules were heat treated in a nitrogen atmosphere at 
$900{ }^{\circ} \mathrm{C}$ for $30 \mathrm{~min}$ to form carbon templates. These were then infiltrated with cerium nitrate solution $\left(\mathrm{Ce}\left(\mathrm{NO}_{3}\right)_{3} \cdot 6 \mathrm{H}_{2} \mathrm{O}, 99 \%\right.$, Sigma Aldrich) using a rotary evaporator under vacuum following two routes ( $i$ and ii below), which aimed to evaluate the influence of the solvent nature and the number of infiltration cycles on the microstructure of the produced ecoceramics:

i) Water was used to dissolve the cerium nitrate and four infiltration/drying cycles were performed, considering previous work by the authors which showed that beyond the fourth cycle the specimens' weight gain is less relevant ${ }^{36,37}$ (hereafter denoted as CG17).

ii) Acetone was selected to dissolve the cerium nitrate solution and one infiltration/drying cycle was performed. The authors have performed preliminary tests (not shown for the sake of brevity) to evaluate the influence of the number of infiltration/drying cycles when using acetone. Results have shown that the use of a higher number of cycles negatively affects the ecoceramic's microstructure, due to an increase in the amount of cerium nitrate deposited inside the cork-carbon template cells. After firing this leads to a decrease in the ecoceramic's porosity, and could jeopardise its envisioned use in solar thermochemical fuel production. Hereafter, this novel material is denoted CG19. It should be highlighted that with this route the goal was to decrease the time and energy consumption (e.g. rotary evaporator) required for the specimens' synthesis.

\section{Cork}

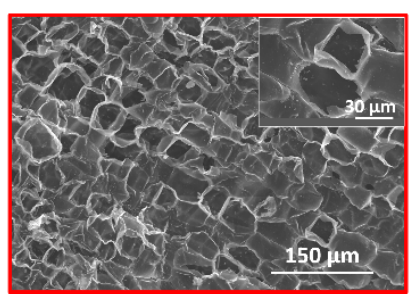

(1)
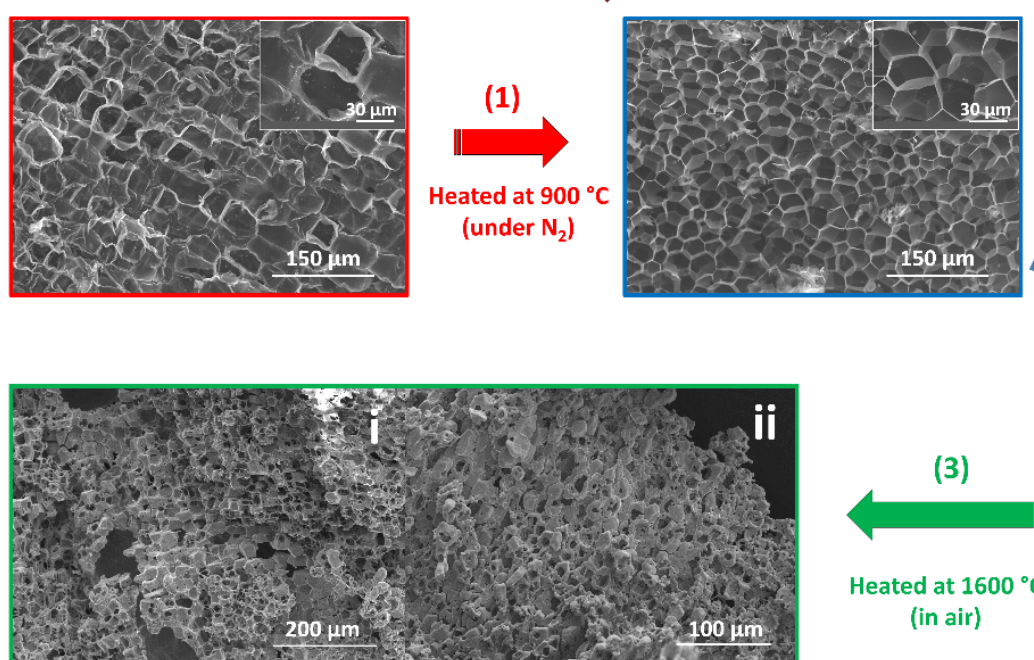

ii

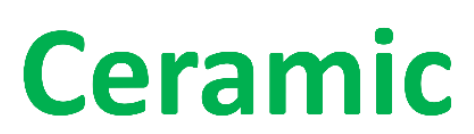

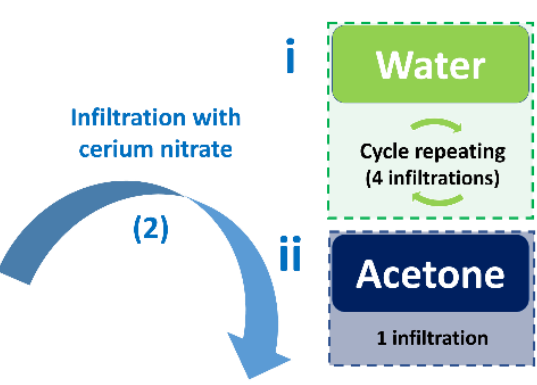

(3)

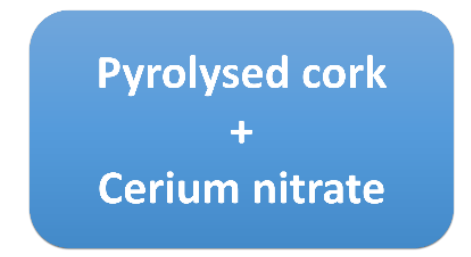


Fig. 1 Scheme of the synthesis protocol for producing cork-derived ceria ecoceramics. Two different synthesis processes were compared, i) using water and ii) using acetone, and the SEM images of the two resulting ceria ecoceramics are also shown.

After the infiltration/drying step (number depending on the synthesis protocol), the specimens were heated in air to $1600{ }^{\circ} \mathrm{C}$ for $30 \mathrm{~min}$ to remove the carbon and calcine the cerium, leaving a pure ceria ceramic while preserving the 3-DOM structure of cork.

Polymeric templated ceria foams (hereafter called CF5), of cylindrical shape (20 $\mathrm{mm}$ in diameter and $20 \mathrm{~mm}$ height), were manufactured by the replication method reported in detail elsewhere. ${ }^{38}$ Briefly, an aqueous slurry with a solid content of 40 vol. $\%$ was prepared from cerium oxide powders (Aldrich Chemistry, ref. 211575, Austria, with an average particle size $\left(d_{50}\right)$ of $1 \mu \mathrm{m}, 99.9 \%$ purity) together with $0.8 \mathrm{wt} . \%$ anionic polyelectrolyte dispersant (Dolapix CE64, Zschimmer \& Schwarz, F.R. Germany). Addition of 5 wt. \% polyvinyl alcohol (PVA, Riedel-de-Haën, F.R. Germany) was made for structure stabilisation in order to prevent the collapse of the foam structure during polymer burnout. The reagents were mixed together for $30 \mathrm{~min}$ in a Pyrex jar at $700 \mathrm{rpm}$. The resulting stock slurry was then used to impregnate an open-cell polyurethane (PU) foam (grade 20DB, manufactured by Flexipol - Espumas Sintéticas S.A., Portugal). The mean cell size of the PU foam was determined to be $\sim 700 \mu \mathrm{m}$ (36 ppi) by using image analysis, and its density is $21 \mathrm{~kg} \mathrm{~m}^{-3} .39$ After drying under controlled temperature and humidity conditions overnight, the samples were heated at $1{ }^{\circ} \mathrm{C} \mathrm{min}-1$ to $500{ }^{\circ} \mathrm{C}$ for $1 \mathrm{~h}$, and subsequently sintered at $1450{ }^{\circ} \mathrm{C}$ for $30 \mathrm{~min}$.

\subsection{Solar reactor for thermochemical $\mathrm{H}_{2} \mathrm{O}$-splitting cycles}

The experimental setup used was developed for investigating high-temperature solid-gas thermochemical reactions in controlled atmospheres using a solar chemical reactor mounted on a medium size solar furnace (MSSF) facility at CNRS-PROMES. It is described in

detail elsewhere, and it is shown in Fig. $2 .^{33}$ Briefly, concentrated solar energy was used to drive the endothermic reduction of ceria, whilst the oxidation step was performed during free cooling without any solar energy supply. The high-temperature process heat was supplied by a horizontal axis solar furnace, composed of a sun-tracking heliostat reflecting 
the incident solar irradiation towards a $2 \mathrm{~m}$ diameter parabolic dish concentrator. The solar reactor consisted of a cavity receiver with a $20 \mathrm{~mm}$ diameter aperture positioned at the focal point of the concentrator. The maximum thermal power delivered by the solar concentrator is about $1.5 \mathrm{~kW}$ for a direct normal irradiation (DNI) of $1 \mathrm{~kW} \mathrm{~m}^{-2}$ (only a fraction of this energy was necessary to reach the maximum operating temperature in the solar reactor, namely 0.8 to $1 \mathrm{~kW}$ actually absorbed by the cavity accounting for incident radiation spillage around the aperture due to concentration defects and attenuation by the glass window due to absorption and reflection). The cavity made of graphite was lined with a surrounding insulation layer and shielded from the ambient atmosphere using a transparent Pyrex glass window. The samples (either cork-templated ceria granules or ceria foam, about 8-12 g) were placed inside an alumina tube (99.7\% purity) with an internal diameter of $20 \mathrm{~mm}$, vertically crossing the cavity. They were supported using a $3 \mathrm{~mm}$ thick $\mathrm{ZrO}_{2}$ felt disc (Zircar Inc., USA) that is chemically inert under the operating conditions to avoid unwanted side reactions. The reaction temperature measurements were carried out using an alumina-shielded B-type thermocouple positioned directly within the reacting sample inside the alumina tube. This cavity-type solar reactor configuration provides homogeneous temperature distribution within the reacting zone where the sample is placed (40 $\mathrm{mm}$ in height). Additional temperature measurements were performed by B-type thermocouples (at the cavity external walls and through the reactor insulation) and by a solar-blind pyrometer (pointing to the tube external wall). Purge gas ( $\mathrm{Ar}, 99.999 \%$ purity, $\mathrm{O}_{2}$ content below $2 \mathrm{ppm}$ ) and $\mathrm{H}_{2} \mathrm{O}$ flowrates were regulated using electronic mass flow controllers and a peristaltic water pump, respectively. Liquid water was injected via a capillary directly into the tube above the reacting sample, and vaporised before reaching the reactive material. The reduction flow rate was set at $0.25 \mathrm{NL} \mathrm{min}{ }^{-1}$ of argon, whereas the oxidation step was performed with $0.21 \mathrm{NL} \mathrm{min}^{-1} \mathrm{H}_{2} \mathrm{O}$ and $0.25 \mathrm{NL} \mathrm{\operatorname {min } ^ { - 1 }} \mathrm{Ar}$ (i.e., 45v\% $\mathrm{H}_{2} \mathrm{O}$ in $\mathrm{Ar}$ ), to keep the residence time of reacting gas constant during each cycle. These gases were fed from the top of the tube, and the product gases exiting from the reactor outlet at the bottom were monitored using devoted gas analysers for $\mathrm{O}_{2}$ and $\mathrm{H}_{2}$.

Prior to each test, residual air in the reactor chamber was removed by successive vacuum pumping and refilling with Ar in order to operate in an inert atmosphere inside the tube. The reactor was first heated in $\mathrm{Ar}$ up to the targeted reduction temperature $\left(\sim 1400^{\circ} \mathrm{C}\right)$. The reduction (endothermic) step consisted of heating the material up to $1400{ }^{\circ} \mathrm{C}$, with a set 
heating rate $\left(\sim 30-40^{\circ} \mathrm{C} / \mathrm{min}\right)$, and maintaining a temperature plateau for $\sim 15 \mathrm{~min}$ until the outlet $\mathrm{O}_{2}$ concentration became low enough, meaning that the ceria reduction was complete and the equilibrium state in the material oxygen stoichiometry was reached. The temperature was then decreased, and the $\mathrm{O}_{2}$ concentration returned to almost zero before switching the gas atmosphere for the oxidation step. The temperature was controlled by adjusting the opening of a shutter placed between the heliostat and the concentrator, thereby adapting the solar energy input to the targeted temperature. The $\mathrm{O}_{2}$ evolution was measured continually using an oxygen analyser with zirconium oxide sensor (SETNAG ${ }^{\mathrm{TM}}$ JC48V, range: 10-10000 ppm, precision: 0.2\%, calibrated with $5040 \mathrm{ppm} \mathrm{O}_{2}$ in $\mathrm{N}_{2}$ ). The temperature was lowered by closing the shutter for the reoxidation (exothermic) step, and $\mathrm{H}_{2} \mathrm{O}$ (balanced with $\mathrm{Ar}$ ) was injected into the reactor chamber to react with the oxygendeficient material and to produce $\mathrm{H}_{2}$. The soaking time of the oxidation step during the temperature decrease (free cooling without any solar power input) was also roughly 15 min to reach reaction completion. $\mathrm{H}_{2}$ concentration in the exhaust gas was measured on-line (concentration as a function of time profiles) by a specific analyser (thermal conductivity detection, Emerson NGA2000; range: $0-10 \% \mathrm{H}_{2}$, precision: $<1 \%$ of full-scale). The amounts of gas produced were then determined by time integration of the gas production rates. Each material was subjected to a minimum of 5 cycles ( 9 for CG19). 

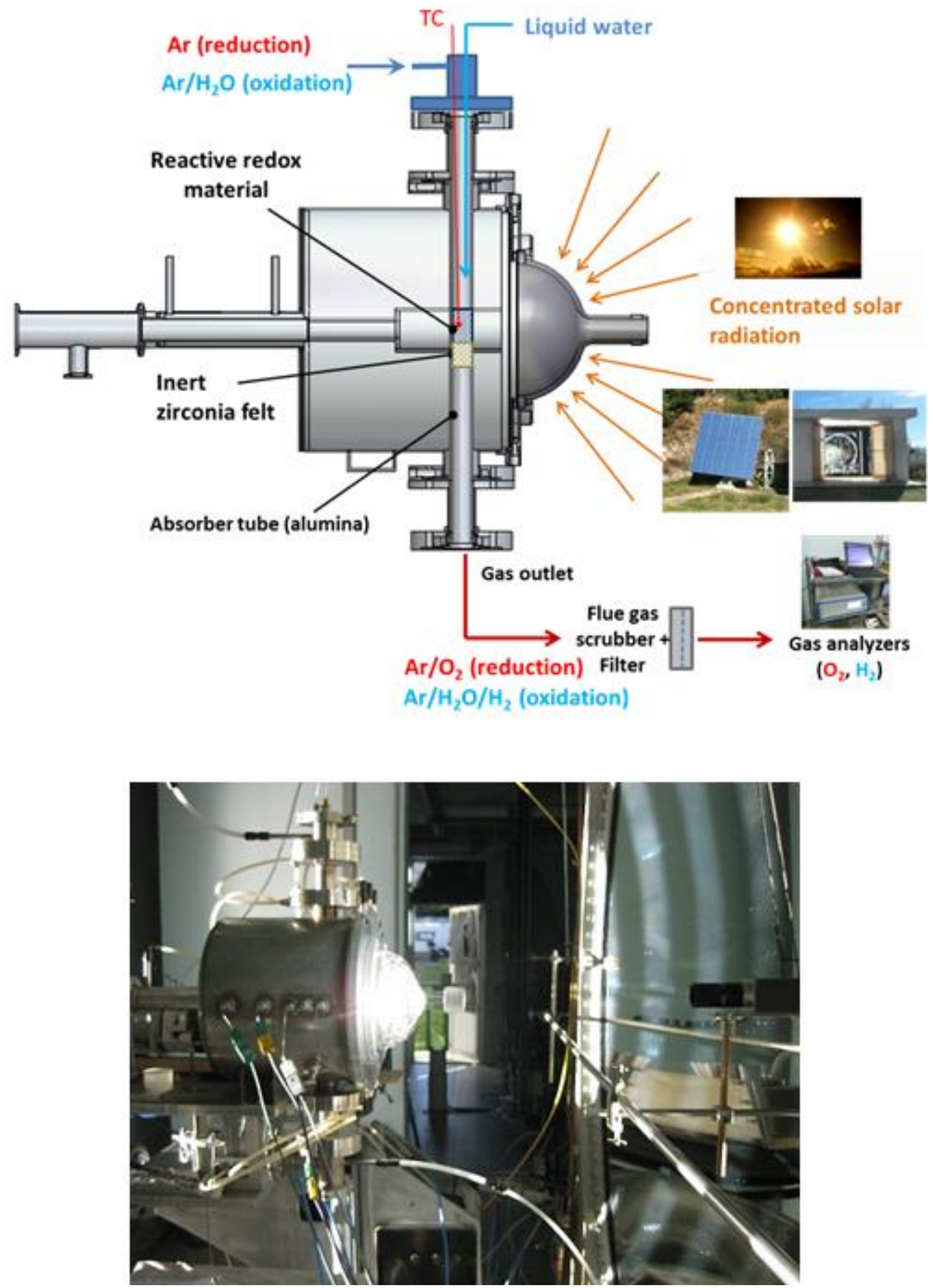

Fig. 2 Schematic and side view of the tubular solar reactor at the focus of the solar concentrator. 


\subsection{Materials characterisation}

Samples were observed by scanning electron microscopy (SEM) using a Philips XL30 FEG (field emission gun), before and after thermochemical cycles, in order to check for morphology changes. SEM secondary electron images were obtained at an acceleration voltage of 5-10 kV. For this study, the samples were not coated with any conductive surface layer.

The true density of the ceria was determined using a AccuPyc 1330 Helium pycnometer (Micromeritics Int. Corp., USA).

Nitrogen adsorption measurements were carried out for CG19 and CF5 samples at -196 ${ }^{\circ} \mathrm{C}$ using Micromeritics ASAP 2020. Before each measurement, the samples were degassed at $4 \times 10^{-3} \mathrm{mbar}$ and at $300{ }^{\circ} \mathrm{C}$ for $12 \mathrm{~h}$.

\section{Results and discussion}

\subsection{Thermochemical redox performance}

The reducibility and $\mathrm{H}_{2} \mathrm{O}$-splitting ability of the $\mathrm{CeO}_{2}$ samples were assessed via successive thermochemical cycles in the solar reactor under real solar irradiation conditions. Both the $\mathrm{O}_{2}$ and $\mathrm{H}_{2}$ rate evolutions, as well as the measured temperatures (inside the reactant $\mathrm{T}_{\text {material }}$ and at the tube external wall $\mathrm{T}_{\text {pyro }}$ ), are shown in Figs. 3, 4 and 5. The temperature of the reduction step was typically about $1400{ }^{\circ} \mathrm{C}$, and was controlled by adjusting the shutter opening in response to the dynamic variations of the DNI owing to the diurnal transient evolution, or to instabilities resulting from the passage of clouds. One can notice that the $\mathrm{O}_{2}$ production was slower than the $\mathrm{H}_{2}$ production. In fact, the oxidation reaction is significantly faster than the reduction for all of the investigated materials. The $\mathrm{O}_{2}$ production rate depends on the heating rate, and is highly sensitive to small temperature changes, which thus denotes that it is controlled mainly by the heat transfer rate. It features a broadened pattern (the total duration of $\mathrm{O}_{2}$ release was around $30 \mathrm{~min}$ ). The release of $\mathrm{O}_{2}$ started at about $1000{ }^{\circ} \mathrm{C}$, the $\mathrm{O}_{2}$ concentration increased with temperature and a peak concentration was measured when approaching the temperature set-point. In contrast, the $\mathrm{H}_{2}$ production rate exhibits a sharpened peak as soon as $\mathrm{H}_{2} \mathrm{O}$ is injected and then the $\mathrm{H}_{2}$ production decreases steadily (the total peak duration is typically around $10 \mathrm{~min}$ ). This is related to the 
fact that the reoxidation reaction started promptly after steam was injected in the reactor at the desired temperature, while the $\mathrm{O}_{2}$-releasing reaction occurred continually during sample heating and the reduction began at a low temperature (about $1000{ }^{\circ} \mathrm{C}$ ) with a slow kinetic rate. The other reason is associated with the different main governing mechanisms. The $\mathrm{O}_{2}$-releasing reaction proceeds via diffusion of $\mathrm{O}^{2-}$ ions inside the solid structure and is heat transfer limited, whereas the $\mathrm{H}_{2}$-generation reaction occurs by rapid surface reaction followed by internal gas diffusion through the porous structure. Two serial steps are involved: reaction at the surface, and diffusion of oxidant species within the bulk of the oxide.

Table 1 summarises the calculated $\mathrm{O}_{2}$ and $\mathrm{H}_{2}$ yields obtained by integrating their production rate versus time profiles as well as thermochemical cycle conditions, including both the reduction and oxidation temperatures, the $\mathrm{Ar}$ and $\mathrm{H}_{2} \mathrm{O}$ gas flow rates and mean DNI measured for each cycle.

Table 1. $\mathrm{O}_{2}$ and $\mathrm{H}_{2}$ production yields during the investigated two-step thermochemical cycles (oxidation was performed during free cooling with water steam injection starting at the mentioned temperature).

\begin{tabular}{|c|c|c|c|c|c|c|c|c|}
\hline Materials & Cycle № & DNI & $\begin{array}{l}\text { Tred } \\
\left({ }^{\circ} \mathrm{C}\right)\end{array}$ & $\begin{array}{l}\text { Toxid } \\
\left({ }^{\circ} \mathrm{C}\right)\end{array}$ & $\begin{array}{c}\mathrm{Ar} \\
\left(\mathrm{NL} \min ^{-1}\right)\end{array}$ & $\begin{array}{c}\mathrm{H}_{2} \mathrm{O} \\
\left(\mathrm{NL} \min ^{-1}\right)\end{array}$ & $\begin{array}{c}\mathrm{O}_{2} \\
\mu \mathrm{mol} / \mathrm{g}\end{array}$ & $\begin{array}{c}\mathrm{H}_{2} \\
\mu \mathrm{mol} / \mathrm{g}\end{array}$ \\
\hline \multirow{6}{*}{ CG17 } & 1 & 965 & 1330 & 880 & 0.25 & 0.205 & 26.9 & 62.0 \\
\hline & 2 & 960 & 1400 & 1050 & 0.25 & 0.205 & 74.4 & 157.0 \\
\hline & 3 & 950 & 1400 & 1050 & 0.25 & 0.205 & 71.5 & 162.3 \\
\hline & 4 & 1010 & 1400 & 1050 & 0.25 & 0.253 & 70.7 & 140.1 \\
\hline & 5 & 980 & 1400 & 1050 & 0.25 & 0.253 & 63.2 & 135.1 \\
\hline & 6 & 950 & 1400 & 950 & 0.25 & 0.253 & 61.0 & 133.9 \\
\hline \multirow{9}{*}{ CG19 } & 1 & 985 & 1400 & 1050 & 0.25 & 0.205 & 63.1 & 125.9 \\
\hline & 2 & 980 & 1400 & 1050 & 0.25 & 0.205 & 52.7 & 113.6 \\
\hline & 3 & 950 & 1450 & 1050 & 0.25 & 0.205 & 88.9 & 171.1 \\
\hline & 4 & 945 & 1400 & 1150 & 0.25 & 0.205 & 47.6 & 101.2 \\
\hline & 5 & 925 & 1400 & 1050 & 0.25 & 0.205 & 49.4 & 104.4 \\
\hline & 6 & 915 & 1400 & 950 & 0.25 & 0.205 & 44.8 & 114.1 \\
\hline & 7 & 950 & 1400 & 1050 & 0.25 & 0.205 & 72.5 & 133.2 \\
\hline & 8 & 945 & 1400 & 1050 & 0.50 & 0.205 & 56.1 & 118.9 \\
\hline & 9 & 940 & 1400 & 950 & 0.25 & 0.205 & 56.1 & 117.3 \\
\hline \multirow{5}{*}{ CF5 } & 1 & 940 & 1400 & 1050 & 0.25 & 0.205 & 44.0 & 95.4 \\
\hline & 2 & 950 & 1400 & 1050 & 0.25 & 0.205 & 49.8 & 115.2 \\
\hline & 3 & 980 & 1400 & 950 & 0.25 & 0.205 & 52.0 & 112.0 \\
\hline & 4 & 1005 & 1400 & 1150 & 0.25 & 0.205 & 52.4 & 102.5 \\
\hline & 5 & 1010 & 1450 & 1050 & 0.25 & 0.205 & 72.2 & 147.4 \\
\hline
\end{tabular}


In the case of CG17 (Fig. 3), two sets of data were obtained using different sample amounts (day 1, $7.88 \mathrm{~g}$; day 2, $8.94 \mathrm{~g}$ ). During the first cycle, in day 1, the heating was stopped at around $1330{ }^{\circ} \mathrm{C}$. The oxygen production of this initial cycle was only $27 \mu \mathrm{mol}$ per $\mathrm{g}$ of ceria, and the corresponding $\mathrm{H}_{2}$ peak rate was $0.6 \mathrm{~mL} \mathrm{~min} \mathrm{~g}^{-1}$. Once the cycle was repeated, the amount of oxygen released during the reduction step at $1400{ }^{\circ} \mathrm{C}$ was $\sim 75$ $\mu \mathrm{mol} \mathrm{g}{ }^{-1}$, corresponding to a reduction yield of $5 \%$, which is in good agreement with data reported previously for pure ceria synthesised by coprecipitation of hydroxides. ${ }^{40}$ The reduction is a thermally activated process that proceeds with continuous oxygen disincorporation from the oxide lattice as the temperature is increased. The reduction rate $\left(\mathrm{O}_{2}\right.$ evolution) thus immediately decreased when the temperature dropped. Concerning the reoxidation step, the reduced CG17 material totally reacted with the water vapour with a fast reaction rate. In addition, the temperature during oxidation step had an influence on the reoxidation rate, as anticipated. The lower the temperature, the higher the $\mathrm{H}_{2}$ production rate (however, the $\mathrm{H}_{2}$ production yield is not affected significantly, as shown in Table 1). This can be explained by thermodynamic limitation, i.e., the exothermic reaction is not favoured by a temperature increase.

The theoretical maximum amount of oxygen released per gram of ceria (corresponding to the total reduction of $\mathrm{Ce}^{4+}$ to $\mathrm{Ce}^{3+}$ ) is $1.45 \mathrm{mmol}$, and the maximum theoretical $\mathrm{H}_{2}$ production is $2.9 \mathrm{mmol} \mathrm{g}^{-1}$. During the reoxidation step at $1050{ }^{\circ} \mathrm{C}$, the maximum $\mathrm{H}_{2}$ production was $162.3 \mu \mathrm{mol} \mathrm{g}^{-1}$ (5.5\% of the theoretical value). These values are low, which justifies the need for further studies on the reduction yield improvement. The increase in water steam flowrate from 0.21 to $0.25 \mathrm{NL} \mathrm{min}^{-1}$ had no significant effect on the oxidation extent, as anticipated, since the $\mathrm{H}_{2}$ yield is closely related to the reduction extent. 

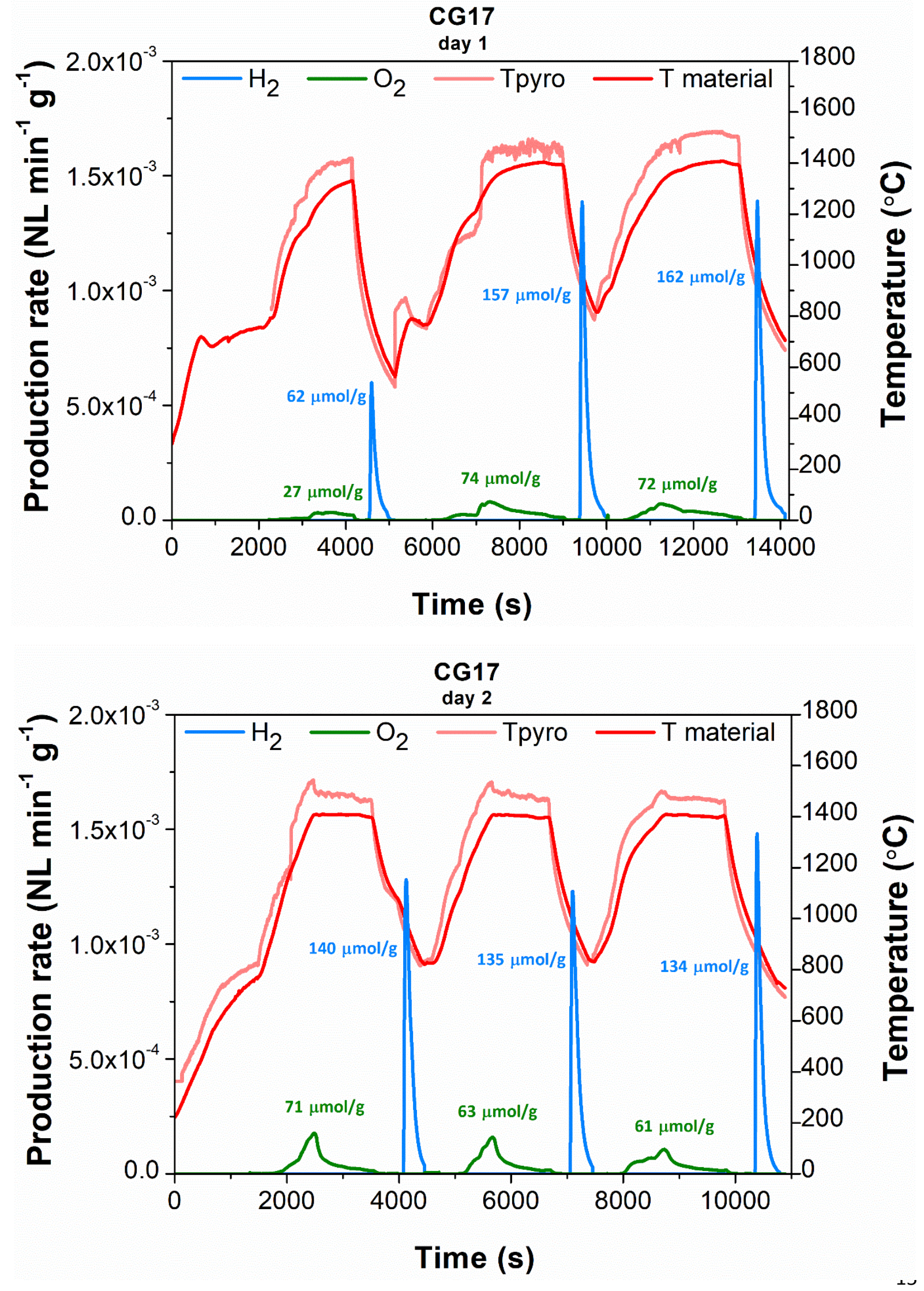
Fig. 3 Time dependent solar thermochemical reduction and re-oxidation profiles for CG17.

The thermochemical performance of CG19 (10.06 g, 9 cycles) follows a similar pattern (Fig. 4), although the material appears to be slightly less reactive than CG17. Indeed, the mean oxygen production was merely $51 \pm 5 \mu \mathrm{mol}$ per g at $1400^{\circ} \mathrm{C}$, i.e., around $30 \%$ decrease, which corresponds to a $\mathrm{H}_{2}$ production yield average of $116 \pm 10 \mu \mathrm{mol} \mathrm{g}^{-1}$ (peak $\mathrm{H}_{2}$ rate of 1.3 $\mathrm{mL} \mathrm{min}^{-1} \mathrm{~g}^{-1}$ ). When the reducing temperature was increased by merely $50^{\circ} \mathrm{C}$ up to $1450^{\circ} \mathrm{C}$, the amount of oxygen released reached $89 \mathrm{\mu mol} \mathrm{g}^{-1}$ (around $75 \%$ increase compared to that obtained at $1400{ }^{\circ} \mathrm{C}$ ). Not surprisingly, the $\mathrm{H}_{2}$ peak rate reached a maximum of around 1.6 $\mathrm{mL} \min ^{-1} \mathrm{~g}^{-1}$ after oxidation at below $1050{ }^{\circ} \mathrm{C}$. As also noticed for CG17, increasing the oxidation temperature from $950{ }^{\circ} \mathrm{C}$ to $1150{ }^{\circ} \mathrm{C}$ resulted in a decrease in $\mathrm{H}_{2}$ yield from 114.1 to $101.2 \mu \mathrm{mol} \mathrm{g}^{-1}$ after reduction at $1400{ }^{\circ} \mathrm{C}$ (Table 1). This is because the peak rate of $\mathrm{H}_{2}$ production increased when decreasing the oxidation temperature below $1150{ }^{\circ} \mathrm{C}$, from 0.55 to $1.12 \mathrm{~mL} \mathrm{~min}^{-1} \mathrm{~g}^{-1}$ (Fig.4, day 2, cycles $\mathrm{N}^{\circ} 4,5,6$ ), while the oxidation duration was shortened (as evidenced by the sharpened $\mathrm{H}_{2}$ production peak). 

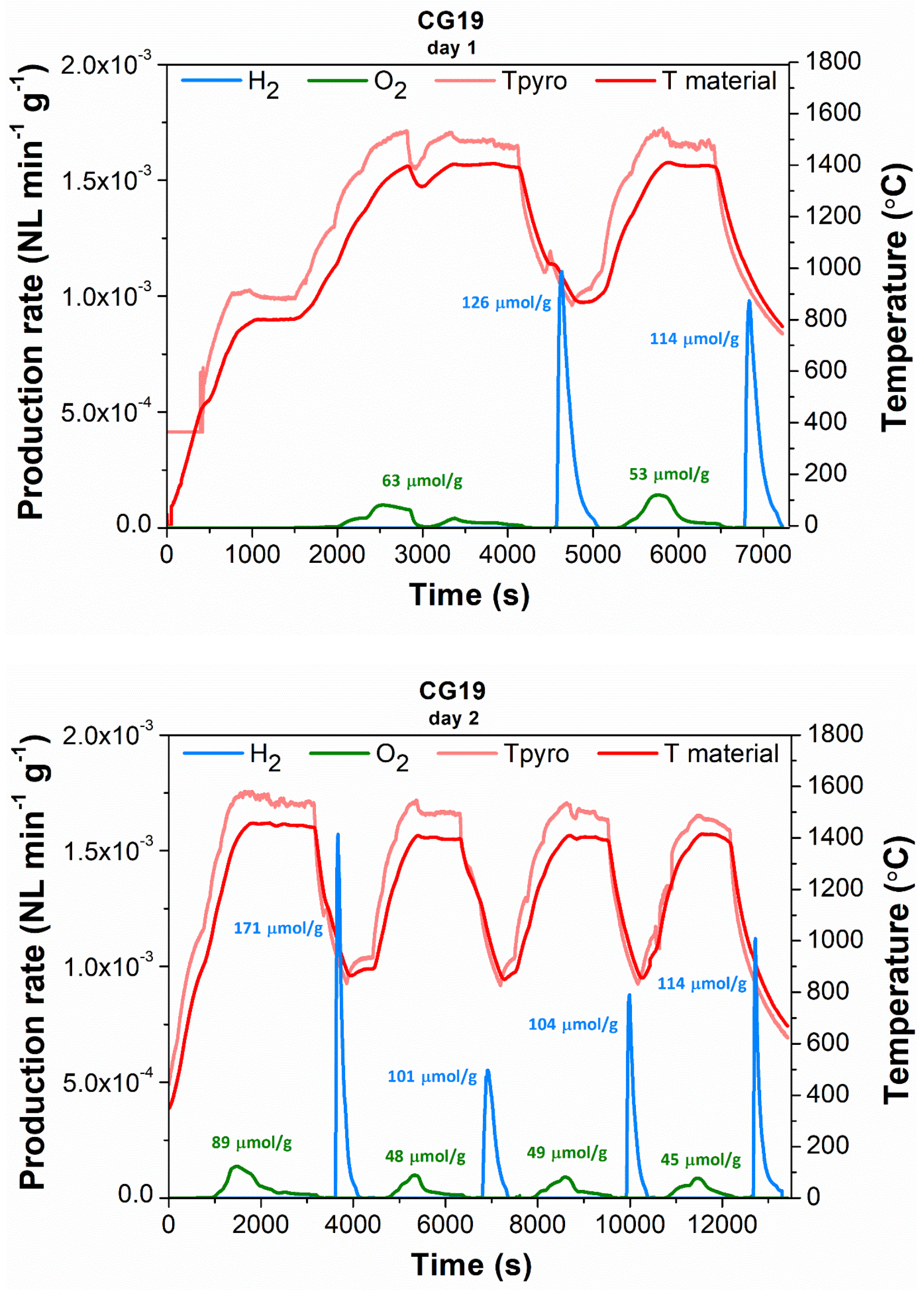


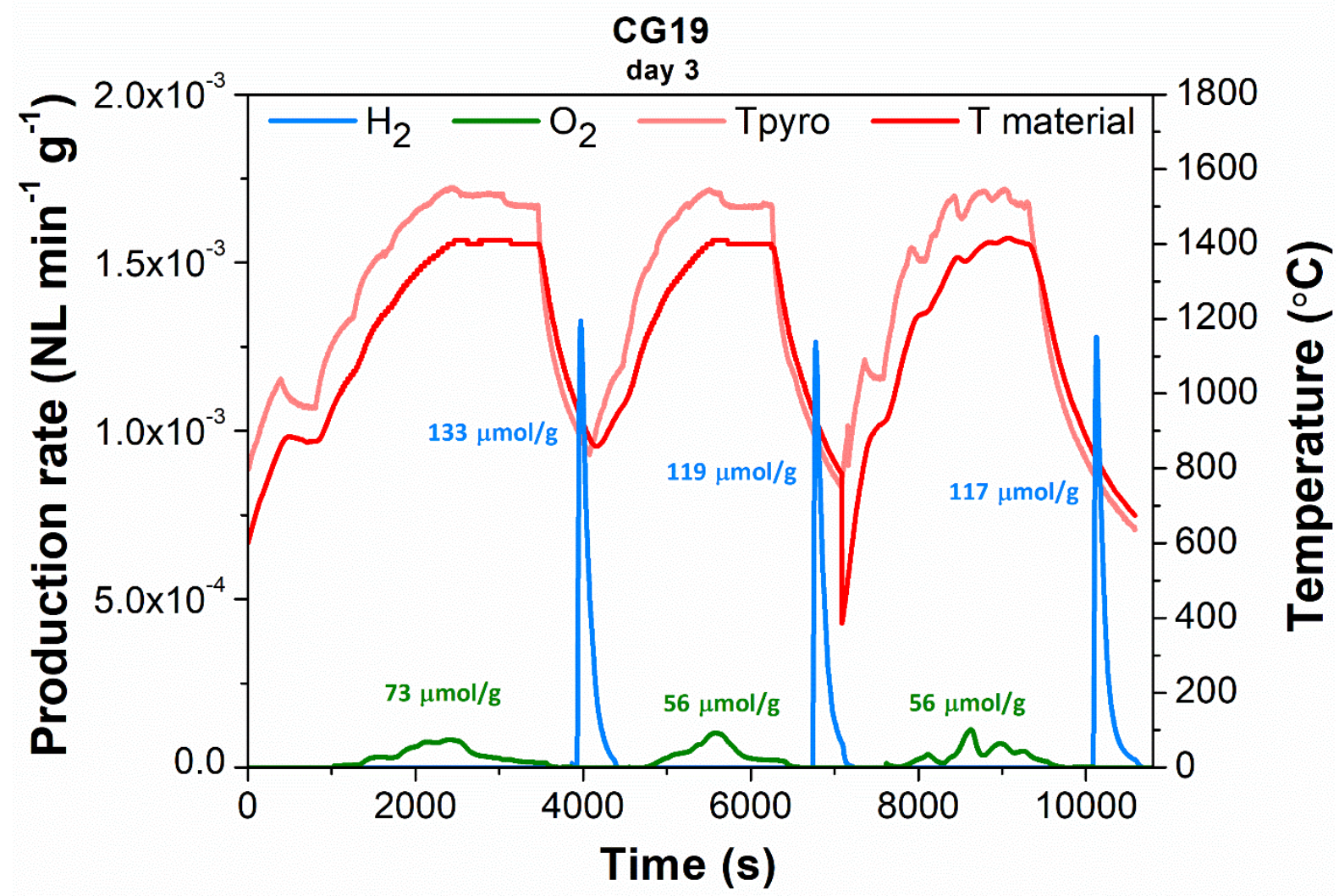

Fig. 4 Time dependent solar thermochemical reduction and re-oxidation profiles for CG19.

Regarding the polyurethane templated ceria CF5 $(12.07 \mathrm{~g})$, five consecutive thermochemical redox cycles were carried out, and the results are shown in Fig. 5. After reduction at $1400{ }^{\circ} \mathrm{C}$, the mean oxygen specific yield was $50 \pm 4 \mu \mathrm{mol} \mathrm{g}{ }^{-1}$, i.e., similar to that obtained for CG19. In contrast, this value compares to $29 \pm 5 \mu \mathrm{mol} \mathrm{g}{ }^{-1}$ obtained for the foams produced and tested in the previous test campaign. ${ }^{33}$ This is related to microstructural features, as shall be discussed later. Again, the increase of reduction temperature from 1400 to $1450{ }^{\circ} \mathrm{C}$ had a significant effect on the oxygen yield, which rose from 50 to $72 \mu \mathrm{mol} \mathrm{g}{ }^{-1}$ (44\% increase), whereas the $\mathrm{H}_{2}$ yield reached a maximum of $147 \mu \mathrm{mol} \mathrm{g}^{-1}$ (corresponding to a production rate of around $0.7 \mathrm{~mL} \mathrm{~min}^{-1} \mathrm{~g}^{-1}$ ). The oxidation kinetics was also made faster by decreasing the temperature of steam injection from 1150 to $950^{\circ} \mathrm{C}$, in accordance to the thermodynamic predictions. The superior reactivity of the cork-structured ceria when compared to ceria foam (CF5) is demonstrated by the significantly enhanced $\mathrm{H}_{2}$ production rate (typically 1-1.4 $\mathrm{mL} \mathrm{min}^{-1} \mathrm{~g}^{-1}$ for CG19 vs. 0.6-0.8 $\mathrm{mL} \mathrm{min}^{-1} \mathrm{~g}^{-1}$ for CF5). 


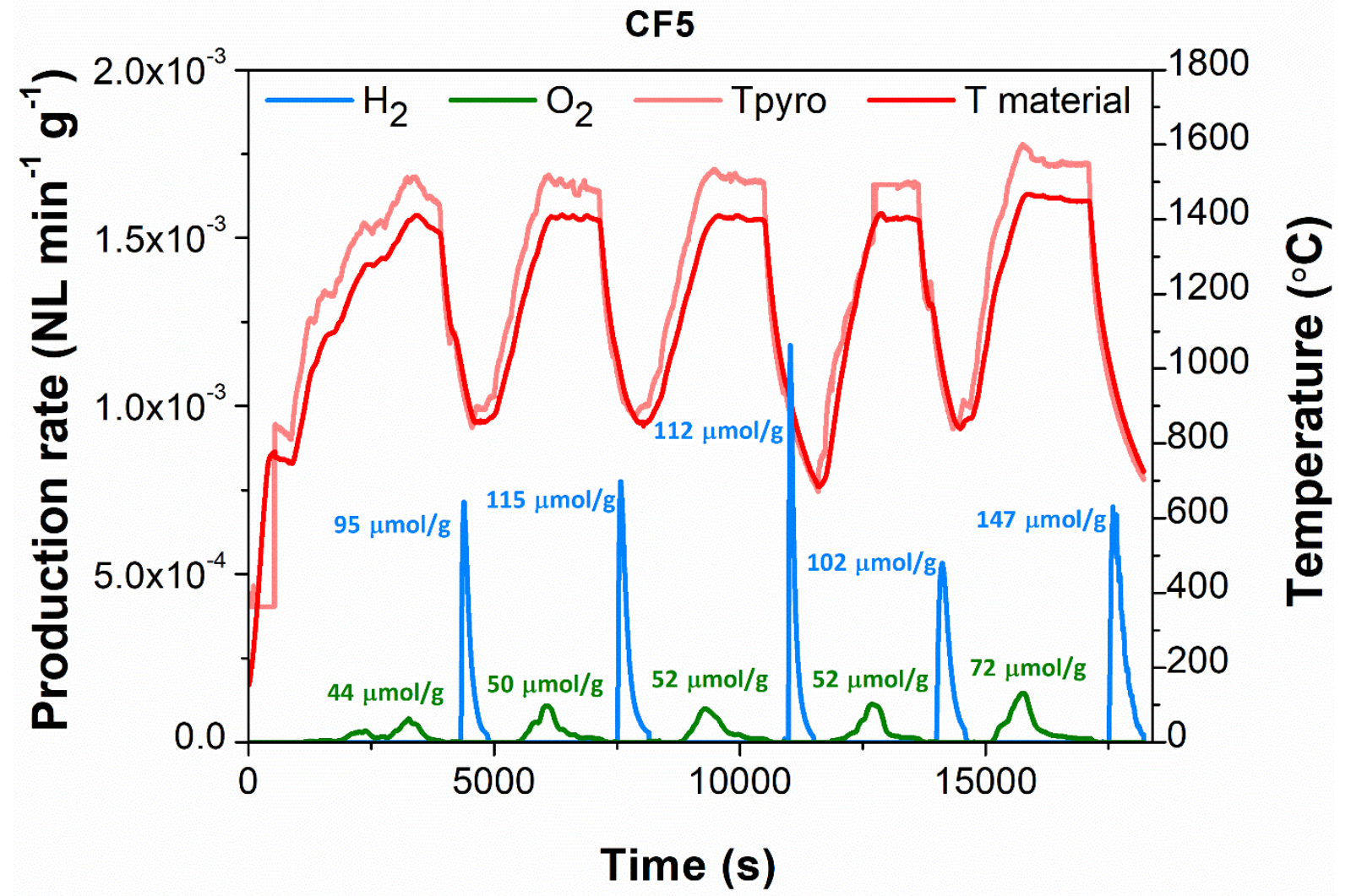

Fig. 5 Time-dependent solar thermochemical reduction and re-oxidation profiles for CF5 over 5 cycles.

Specific yields of $\mathrm{O}_{2}$ and $\mathrm{H}_{2}$ convey important information for the solar reactor design. At a reduction temperature of $\mathrm{T}=1400^{\circ} \mathrm{C}$ and an oxygen partial pressure of $\mathrm{pO}_{2}=5 \times 10^{-6} \mathrm{~atm}$ (assuming that oxygen impurities in Ar are less than $2 \mathrm{ppm}$ ), pure ceria was estimated to release about $0.1 \mathrm{mmol} \mathrm{g}^{-1} \mathrm{O}_{2}$ at equilibrium (0.04-0.07 $\mathrm{mmol} \mathrm{g}^{-1}$ in the present study). ${ }^{41}$ This can be related to the fact that the reduction from $\mathrm{Ce}^{4+}$ to $\mathrm{Ce}^{3+}$ causes the crystal lattice to expand, which has been ascribed to the ionic radius of $\mathrm{Ce}^{4+}(0.097 \mathrm{~nm})$ being smaller than $\mathrm{Ce}^{3+}(0.114 \mathrm{~nm})$, resulting in a stress that supresses further reduction. ${ }^{42}$ However, electronic structure calculations, using density functional theory based on quantum mechanical simulations, show that this hypothesis is incorrect. ${ }^{43}$ The formation of $\mathrm{Ce}^{3+}$ is not responsible for ceria expansion, but rather ceria expands because of outward relaxation from the Ovacancy due to non-counterpoised anion-cation attraction to the $\mathrm{O}$ anion opposite the vacancy. Therefore, the effect of dopants on ceria to facilitate solar thermochemical gas splitting cycles needs to be re-evaluated. ${ }^{44,45}$ When $\mathrm{O}$-vacancies form, each removed $\mathrm{O}^{2-}$ 
anion releases two electrons to the ceria bulk; these electrons localize on two $\mathrm{Ce}^{4+}$ reducing them to $\mathrm{Ce}^{3+}$ cations:

$$
2 C e_{C e}^{X}+O_{O}^{X} \rightarrow V_{\ddot{O}}+2 C e_{C e}^{\prime}+\frac{1}{2} O_{2}(g)
$$

where $C e_{c e}^{X}$ indicates a $\mathrm{Ce}^{4+}$ cation on a cerium lattice site, $O_{O}^{X}$ an $\mathrm{O}^{2-}$ anion on an oxygen lattice site, $C e_{C e}^{\prime}$ a $\mathrm{Ce}^{3+}$ cation on a cerium lattice site and $V_{\ddot{O}}$ a vacancy on an oxygen lattice site that has a $2+$ charge to maintain charge neutrality. Even though Kröger-Vink notation provides a useful framework for thinking about defects and accounting for charges, nuclei are the positive charges in materials and no nucleus occupies the vacancy sites. Therefore, the search continues for metal oxides capable of yielding high solar-to-fuel energy conversion efficiencies $\left(\eta_{\text {solar-to-fuel }}\right) .^{46}$ In this respect, paired charge compensating doped ceria is a novel approach deserving more attention.

Based on TG data, it has been shown that $\mathrm{Ce}_{0.9} \mathrm{Y}_{0.05} \mathrm{Nb}_{0.05} \mathrm{O}_{2}$ reached the highest anticipated $\eta_{\text {solar-to-fuel }}$ of $31 \%$ for $\mathrm{H}_{2}$ production compared to $26 \%$ achieved by undoped ceria, using a reduction temperature of $1500{ }^{\circ} \mathrm{C}$ and oxidation temperatures of $1200-1250$ ${ }^{\circ} \mathrm{C}$, and assuming $90 \%$ heat recovery gas efficiency. ${ }^{51}$

Taking into account the peak $\mathrm{H}_{2}$ production rate obtained for CG19 (and high heating value of $\mathrm{H}_{2}=286 \mathrm{~kJ} / \mathrm{mol}$ ), the maximum $\eta_{\text {solar-to-fuel }}$ was estimated to be $0.34 \%$ (for $1 \mathrm{~kW}$ solar thermal power input absorbed in the solar reactor), while average efficiencies were about $0.28 \%$ for CG and $0.21 \%$ for CF materials. These values for a real lab-scale on-sun reactor system are quite low given the low amount of processed ceria in the solar tubular reactor and could thus be enhanced by both increasing the oxide mass loading and up-scaling the reactor (inherently reducing heat losses). The estimated efficiencies derived from experimental studies are scarce to date, but of major importance to provide insights into the performance of real on-sun reactor systems. They usually differ from the projected ideal efficiencies obtained from thermodynamic analyses (in which kinetic limitation aspects are bypassed) that predict the maximum efficiencies theoretically achievable under various assumptions (operating conditions, heat recovery from gas and solid phases,...). ${ }^{52}$ The local $\mathrm{pO}_{2}$ can also be higher around the sample at the particle surface due to the $\mathrm{O}_{2}$ release, which hinders oxygen removal from the crystal lattice. This suggests that mass transfer 
limitations may play an important role on the rate of reduction reaction of ceria at this temperature.

The evolved $\mathrm{H}_{2} / \mathrm{O}_{2}$ ratio is $2.1 \pm 0.2$, i.e. close to the stoichiometric value. In some cases, this ratio is higher than 2 , because the reduced species that did not react during a previous oxidation at a higher temperature can be oxidised at a lower temperature.

These results point out the superior reactivity of the cork-templated ceria, suggesting that the morphology of the material does indeed affect the redox performance. This is also shown by the average $\mathrm{H}_{2}$ and $\mathrm{O}_{2}$ yield values over three comparable cycles (2-4) for CG17, CG19 and CF5 depicted in Fig. 6.

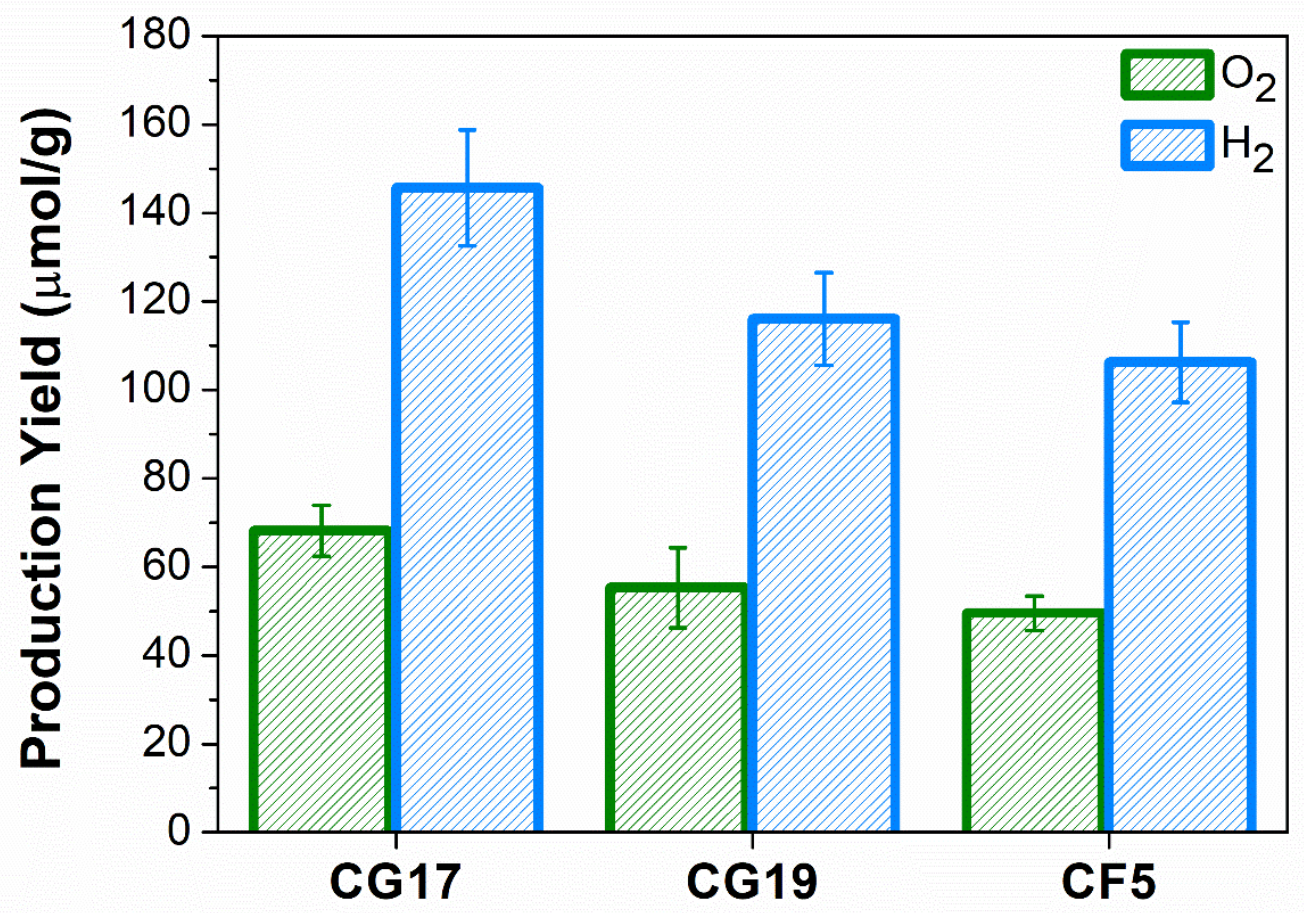

Fig. 6 Comparison of average $\mathrm{O}_{2}$ and $\mathrm{H}_{2}$ production yields over cycles 2-4 for CG17 (cork ecoceramic with aqueous impregnation), CG19 (cork ecoceramic with acetone impregnation) and CF5 (polymer replicated foam) after reduction at $1400^{\circ} \mathrm{C}$.

This is similar to the findings published previously for solar driven thermochemical splitting of $\mathrm{CO}_{2}$ by cork derived ceria ecoceramics and polymer replicated ceria foams. ${ }^{33}$ In that case, $\mathrm{O}_{2}$ was produced in the reduction step, and $\mathrm{CO}_{2}$ then split to produce $\mathrm{CO}$ in the 
oxidation step. For three comparable cycles of $1400{ }^{\circ} \mathrm{C}-1050{ }^{\circ} \mathrm{C}$, the total CO yield was $402.0 \mu \mathrm{mol} / \mathrm{g}$ for the cork ecoceramic (average $=134.0 \mu \mathrm{mol} / \mathrm{g}$ per cycle), and only 210.7 $\mu \mathrm{mol} / \mathrm{g}$ for the replicated foam (average $=70.2 \mu \mathrm{mol} / \mathrm{g}$ per cycle) ${ }^{33}$

CG17 was produced using the same method as the previous samples which were tested for $\mathrm{CO}_{2}$ splitting, ${ }^{33}$ using water as the solvent for impregnation with cerium nitrate, and we found that four impregnations cycles produced the optimum quantity of material. ${ }^{37}$ However, we observed that using so many cycles had a negative effect on the final microstructure of the ecoceramic, as the cerium nitrate began to be deposited inside the cork-carbon template cells, effectively filling them in. This led to a decrease in the porosity of the sintered ecoceramic, which is a vital factor in solar thermochemical fuel production. Therefore, we also experimented with reducing the number of infiltrations required to just one by using acetone as the infiltration solvent, CG19. Acetone wets the hydrophobic carbon surface better, and is also much easier and quicker to evaporate.

Another motive for this route was to decrease the time and energy consumption during impregnation, although it must be noted of course that acetone is a less sustainable/green solvent compared to water. The acetone could be collected after evaporation and reused, as it condenses and is captured in the rotary evaporator.

What these results show is that the "greener" synthesis route, using water as the solvent, produces a superior material (CG17) to the quicker, but less sustainable, route using acetone (CG19). The results in Table 1 clearly demonstrate that CG17 was better at producing $\mathrm{H}_{2}$ than CG19. For cycles 2-6, all at $1400{ }^{\circ} \mathrm{C}-1050{ }^{\circ} \mathrm{C}, \mathrm{CG} 17$ produced a total $\mathrm{H}_{2}$ yield of $728.4 \mu \mathrm{mol} / \mathrm{g}$ (average $=145.7 \mu \mathrm{mol} / \mathrm{g}$ ), compared to just $587.9 \mu \mathrm{mol} / \mathrm{g}$ for CG19 (average $=116.1 \mu \mathrm{mol} / \mathrm{g}$ ). The first cycle for CG17 is ignored as the ceria has not been optimally reduced. The only cycle in which CG19 outperformed CG17 was cycle 3, in which CG17 produced $162.3 \mu \mathrm{mol} / \mathrm{g}$ at $1400{ }^{\circ} \mathrm{C}$ and CG19 produced $171.1 \mu \mathrm{mol} / \mathrm{g}$ at $1450{ }^{\circ} \mathrm{C}$. As anticipated, the $\mathrm{O}_{2}$ yield for this cycle is also higher for CG19 $(88.9 \mu \mathrm{mol} / \mathrm{g}$ vs. $71.5 \mu \mathrm{mol} / \mathrm{g}$ for (G17), in view of the fact that raising the temperature by merely $50{ }^{\circ} \mathrm{C}$, from 1400 to $1450{ }^{\circ} \mathrm{C}$, has a noticeable effect on the reduction extent, thus explaining why the highest $\mathrm{H}_{2}$ yield was obtained for this particular cycle where CG19 was reduced more than in any other cycle (a similar trend was observed in cycle 5 for CF5). The average values of $\mathrm{H}_{2}$ and $\mathrm{O}_{2}$ production for CG17 and CG19 over cycles 2-4 are contrasted in Fig. 6 . Therefore, we will 
continue with the greener and more sustainable aqueous synthesis route in any future ceria ecoceramics production. It should be noted that despite the unavoidable variations between the cork powder batches used (a natural product from various trees of different ages and geographical positions) for the $\mathrm{CO}_{2}$ splitting study and in this work, similar trends are observed. In both cases the cork ecoceramic has significantly greater fuel and $\mathrm{O}_{2}$ production than the replicated foam ceria.

Basically, the rationale for the increase in both $\mathrm{CO}$ and $\mathrm{H}_{2}$ yields observed for the corktemplated ceria materials compared to the ceria foams counterparts is that the small cell size of the cork combined with interconnected pore system result in a larger geometric area being exposed to the gas stream and facilitate gas phase species transport, thereby promoting a more effective oxidation of ceria under flowing $\mathrm{CO}_{2}$ or steam water.

Table 2 compares the data obtained in the present study with that reported in the literature under similar conditions. It is noteworthy that the values in this table refer to studies performed by TG analysis and tests carried out using conventional heating sources (with one exception). Clearly, CG17 performs better than the other materials reduced at $1400{ }^{\circ} \mathrm{C}$. A ceria felt made of compressed ceria fibres had superior $\mathrm{H}_{2}$ yields when reduced at a higher temperature of $1450{ }^{\circ} \mathrm{C}$ and oxidised at a lower temperature of $900{ }^{\circ} \mathrm{C},{ }^{47}$ and this felt also produced superior results to CG17-like cork-derived ceria for thermochemical $\mathrm{CO}_{2}$ splitting. ${ }^{28}$ However, as discussed in a review of the effects of morphology on this process, ${ }^{23}$ this was very much a dense $2 \mathrm{D}$ material of compressed fibres, and would be problematic to extend to a 3D structure to convert sizeable quantities of water to hydrogen. A considerable degradation of the $\mathrm{CeO}_{2}$ after exposure to high-flux radiation was also observed. ${ }^{53}$ Furthermore, the low thermal conductivity of the ceria felt $\left(1.3 \mathrm{~W} \mathrm{~m}^{-1} \mathrm{~K}^{-1}\right.$, at $\left.1000{ }^{\circ} \mathrm{C}\right)$ resulted in an undesired temperature gradient across the felt, so that a gradient in the extent of $\mathrm{CeO}_{2}$ reduction must be assumed. This indicates that macroporous ceria structures (e.g. reticulated foams, cork-templated ecoceramics) that enable penetration and volumetric absorption of concentrated solar radiation ought to be used in order to obtain a more homogeneous temperature distribution. 
Table 2 Experimental $\mathrm{H}_{2}$ yields for various materials used in thermochemical $\mathrm{H}_{2} \mathrm{O}$ splitting cycles.

\begin{tabular}{|lllclcc|}
\hline \multicolumn{1}{|c}{ Materials } & Structure & $\begin{array}{c}\text { Tred } \\
\left({ }^{\circ} \mathbf{C}\right)\end{array}$ & $\begin{array}{c}\text { Toxid } \\
\left({ }^{\circ} \mathbf{C}\right)\end{array}$ & \multicolumn{1}{c|}{ Method } & $\begin{array}{c}\mathbf{H}_{2} \text { yield } \\
(\mathbf{m L} / \mathbf{g})\end{array}$ & Ref. \\
\hline $\begin{array}{l}\mathrm{CeO}_{2-x} \mathrm{Fe}_{2} \mathrm{O}_{3} \\
(\mathrm{Ce}: \mathrm{Fe}=8.9: 1.1)\end{array}$ & Powder & 1400 & 1000 & IR-image heating & 1.9 & 16 \\
$\mathrm{NiFeO}_{4}$ & Powder & 1500 & 1000 & IR-heating & 3.4 & 16 \\
$\mathrm{CeO}_{2}-\mathrm{Fe}_{2} \mathrm{O}_{3}$ & Powder & 1400 & 1000 & IR-heating & 2.26 & 15 \\
${\mathrm{YSZ}-\mathrm{Fe}_{3} \mathrm{~N}_{4}}_{\mathrm{Ce}_{0.75} \mathrm{Zr}_{0.25} \mathrm{O}_{2-\delta}}$ & Powder & 1500 & 1000 & IR-heating & 1.77 & 15 \\
$\mathrm{CeO}_{2}$ & Powder & 1450 & 1045 & TGA & 5.4 & 47 \\
$\mathrm{CeO}_{2}$ & Powder & 1400 & 1050 & TGA & 2.6 & 50 \\
$\mathrm{CeO}_{2}$ & Powder & 1400 & 1000 & IR-heating & 0.33 & 15 \\
$\mathrm{CeO}_{2}$ & Fonolith & 1500 & 800 & TGA & $8.5 \pm 0.6$ & 48 \\
$\mathrm{CeO}_{2}$ & Monolith & 1450 & $\sim 900$ & Xe-arcs & 4.18 & 53 \\
$\mathrm{CG} 17^{\mathrm{CG} 19}$ & 3-DOM & 1400 & 500 & IR-heating & 3.19 & 49 \\
$\mathrm{CF5} 5$ & 3-DOM & 1400 & 1050 & Solar-heating & 3.3 & This work \\
\hline
\end{tabular}

The best results in Table 2 are for a porous monolith made from ceria powder and $30 \mathrm{wt} \%$ starch, to produce a sintered monolith with $\sim 70 \%$ porosity (sintered at $1350{ }^{\circ} \mathrm{C} / 5 \mathrm{~h}$, then annealed at $1500{ }^{\circ} \mathrm{C} / 3 \mathrm{~h}$, specific surface area $\left.=0.1 \mathrm{~m}^{2} / \mathrm{g}\right) .{ }^{43}$ However, this was cycled between $1500{ }^{\circ} \mathrm{C}$ and $800{ }^{\circ} \mathrm{C}$, giving a very wide temperature swing of $700{ }^{\circ} \mathrm{C}$, compared to the $350{ }^{\circ} \mathrm{C}$ used by us in this paper. The hydrogen productivity was very high $(8.5 \mathrm{~mL} / \mathrm{g}$ in the first cycle), but then decreased with repeated cycles to $\sim 6 \mathrm{~mL} / \mathrm{g}$ after 100 cycles, and the $\mathrm{H}_{2}$ production rate likewise fell from $\sim 3.2 \mathrm{~mL} \mathrm{~min}^{-1} \mathrm{~g}^{-1}$ to $\sim 1.5 \mathrm{~mL} \mathrm{~min}^{-1} \mathrm{~g}^{-1}$ after 100 cycles. Beyond $\mathrm{H}_{2}$ production yields, material stability is an essential criterion for a viable thermochemical process. The decrease in reaction rate was related to an increase in grain size of the porous monolith structure, from $\sim 5 \mu \mathrm{m}$ to $15-20 \mu \mathrm{m}$ after $>100$ cycles at 1500 ${ }^{\circ} \mathrm{C}^{43}$ which indicates the importance of decreasing the reduction temperature of $\mathrm{CeO}_{2}$ to avoid such undesirable losses in fuel production, for example to the $1400{ }^{\circ} \mathrm{C}$ used in this paper for reduction step.

\subsection{Material microstructure and stability}

The BET-specific surface area, measured by $\mathrm{N}_{2}$ adsorption, was 0.31 and $0.25 \mathrm{~m}^{2} \mathrm{~g}^{-1}$ for CG19 and CF5, respectively. This would explain the slightly higher hydrogen yields obtained 
for GC19 compared to their CF5 counterparts. Attempts to increase redox kinetics by increasing the specific surface area of ceria resulted in temporary improvements in fuel production rate, owing to poor stability of nanostructures as loss in pore volume reduces the solid surface available for the redox reactions. Hence, stabilisation of nano-scale structural features is key to engineering more efficient ceria materials for enhanced solar thermochemical fuel production. ${ }^{55}$

Studies to identify factors affecting the efficiency of solar thermochemical cycles have been performed. ${ }^{46,48,56}$ In a reactor without heat recuperation, pure ceria can theoretically achieve a maximum thermochemical efficiency of roughly $25 \%$ (at a $\mathrm{pO}_{2}$ of $1 \times 10^{-6} \mathrm{~atm}$ ) for a given set of conditions. Knowledge of the oxygen non-stoichiometry as a function of oxygen partial pressure (or, more strictly, oxygen activity) and temperature is crucial, as this determines the maximum quantity of fuel that can be produced in a single cycle for a given quantity of ceria. ${ }^{48}$ Regardless of the material structure and morphology, the main limitation of the ceria redox cycle is, therefore, the thermal reduction step, as pure ceria is difficult to reduce $\left(\delta\right.$ is generally limited to $0.025-0.093$, at $1500{ }^{\circ} \mathrm{C}$, for oxygen partial pressures at $0.001 \mathrm{~atm}$ and $1 \times 10^{-6} \mathrm{~atm}$, respectively), ${ }^{56}$ but it is readily oxidised under favourable conditions.

The cycling stability of the ceria-based materials developed was demonstrated under real solar irradiation conditions.

CG17 produced a cumulative amount of $\mathrm{O}_{2}$ and $\mathrm{H}_{2}$ of 341 and $728 \mu \mathrm{mol} \mathrm{g}{ }^{-1}$, whereas CF5 produced 270 and $573 \mu \mathrm{mol} \mathrm{g}{ }^{-1}$ of $\mathrm{O}_{2}$ and $\mathrm{H}_{2}$, respectively, over 5 cycles, thus yielding a $\mathrm{H}_{2} / \mathrm{O}_{2}$ ratio of about 2 . The reduction temperature strongly influenced the reduction extent, and thus in turn, the $\mathrm{H}_{2}$ production yield, while the oxidation temperature mainly affected the $\mathrm{H}_{2}$ production rate. The enhanced redox activity and $\mathrm{H}_{2}$ splitting capacity of the corktemplated ceria material when compared with the CF5 foam was revealed. ${ }^{33}$

The amounts of $\mathrm{H}_{2}$ produced during the $\mathrm{H}_{2} \mathrm{O}$ splitting step using CG17 were in the range of $134-162 \mu \mathrm{mol} \mathrm{g}^{-1}$ (similar to that obtained for $\mathrm{CO}_{2}$ splitting at $1400{ }^{\circ} \mathrm{C}$ in the range of 120 $150 \mu \mathrm{mol} \mathrm{g}^{-1}$ CO produced under the same conditions). ${ }^{33}$ To aid in the interpretation of the reactive properties of these materials, their microstructure was characterised by means of SEM after thermochemical cycling.

The morphologies of CG17, CG19 and CF5, paired with the observed performance above, give significant insight into the behaviour of these materials under thermal cycling. Both 
CG17 and CG19 exhibit a cork-like microstructure, with cells of $\sim 25 \mathrm{~mm}$ diameter and $\sim 1$ $\mu \mathrm{m}$ cell wall thickness, despite the grain growth which occurred during their sintering at $1600{ }^{\circ} \mathrm{C}$ (Fig. 7). However, it was observed that in much of the material an "inverse" cork structure has formed, owing to the fact that an excess of ceria precursor solution has flooded the carbonised cork skeleton, and filled some of the cells completely. It can be seen in Fig. 7 that both the porous cork structure, and this non-porous "inverse" cork structure, co-exist in the same granule of CG17 (Fig. 7a). This is particularly evident in the case of CG19 (Fig. 7c). Therefore, despite our attempts to reduce this "inverse" cork structure from happening with the employment of acetone based impregnation, it would appear to have led to the opposite effect, and this also explains the lower $\mathrm{H}_{2}$ yield of $\mathrm{CG} 19$ compared to CG17. Further optimisation of this material, and avoidance of this "inverse" cork structure, will inevitably result in further enhancement of their redox abilities for $\mathrm{H}_{2} \mathrm{O}$ splitting.

After the thermochemical cycling, the CG17 cells retained their original size (mean size of about $25 \mu \mathrm{m}$ ) as shown in Fig. 7, and so the as-sintered structure was maintained after several cycles, thus explaining that no significant loss in reactivity performance was observed in repetitive cycling. The shift between the $\mathrm{Ce}^{3+}$ to $\mathrm{Ce}^{4+}$ states results in the formation of lattice defects and high oxygen mobility in the ceria lattice, which in turn can lead to a strong catalytic potential. Therefore, the nanostructure of the cork-templated ceria ecoceramic is inherently unstable, and the presence of spherical particles observed (Fig. $7 \mathrm{~b}$ and $7 d$ ) is attributed to a reduction in surface free energy upon sintering at $1600^{\circ} \mathrm{C}$. 

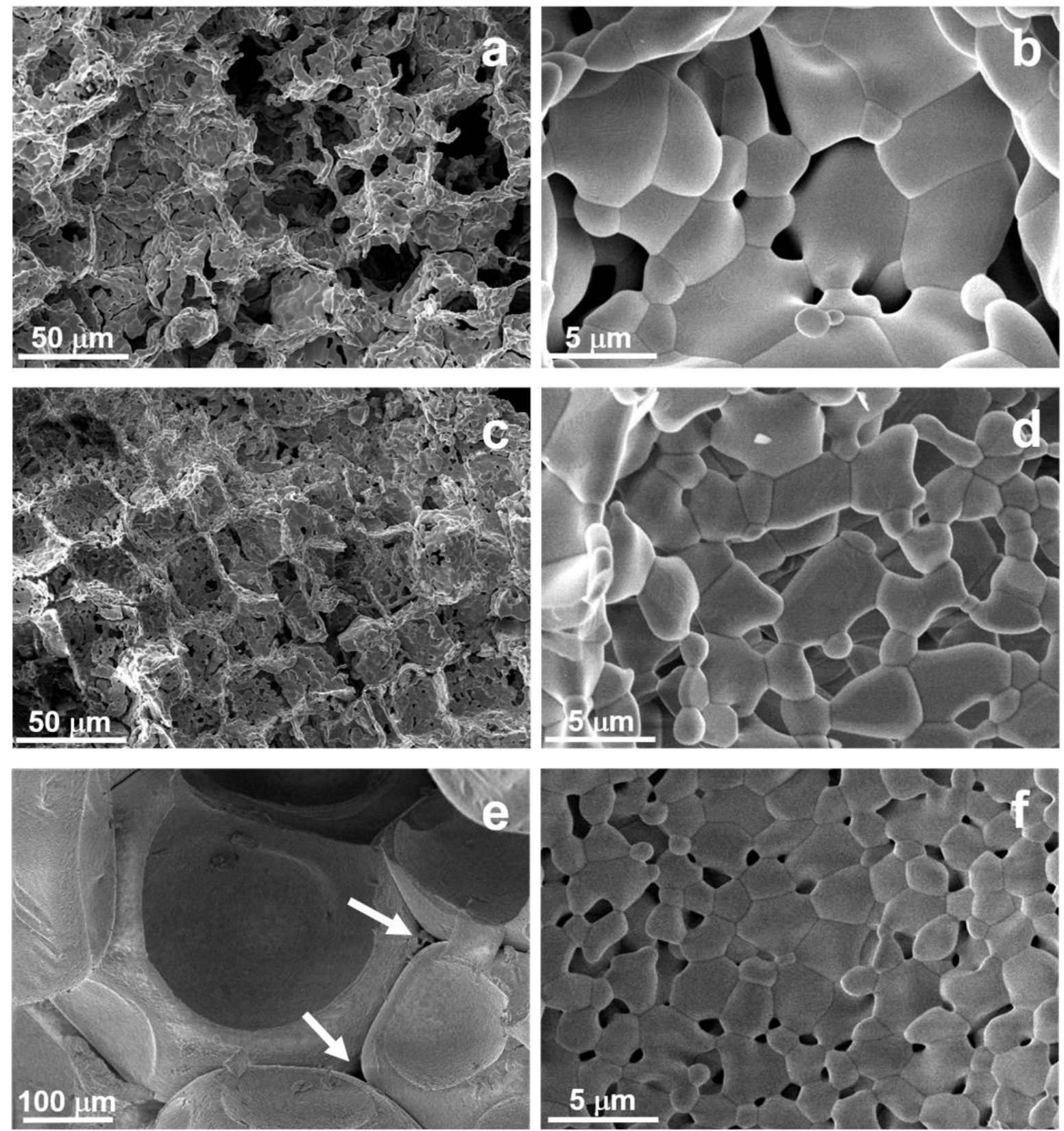

Fig. 7 SEM micrographs showing the microstructure of CG17 ( $a$ and b), CG19 (c and d) and CF5 (e and f) after thermochemical $\mathrm{H}_{2} \mathrm{O}$ splitting cycles.

No significant differences can be observed between CG17 and CG19 (Fig. 7a-d), except that the pore size of cell walls for CG19 is greater than that of their CG17 counterparts. This would explain why their reactivity is slightly lower with respect to $\mathrm{H}_{2} \mathrm{O}$ splitting via the two step thermochemical cycle. This may be an artefact of the variations in their synthesis 
processes.

In contrast, the microstructure of the as-sintered CF5 shows the typical features of ceramic foams produced by the replication method, in particular the hollow nature of the struts which can be seen in Fig. 7e (indicated by arrows). The bulk density of the CF5 material was determined to be $1.03 \pm 0.03 \mathrm{~g} \mathrm{~cm}^{-3}$ (based on mass and volume measurements), which corresponds to a porosity of $\sim 87 \%$, taking into account that the true density of ceria measured by helium pycnometry was $7.65 \mathrm{~g} \mathrm{~cm}^{-3}$.

Average cell diameters were determined to be $575 \pm 55 \mu \mathrm{m}$, whereas the mean strut thickness was $50 \pm 5 \mu \mathrm{m}$, expressed by its transverse length, based on measurements performed on 10 randomly selected cells, observed by SEM.

Although the grain size remained small $(<5 \mu \mathrm{m})$, residual interconnected porosity around the micron-sized grains is evident in spite of the fact that the fine powder used $\left(d_{50}\right.$ below 1 $\mu \mathrm{m})$ makes it very reactive at the sintering temperature of $1450{ }^{\circ} \mathrm{C}$. Unlike the case of $\mathrm{CF},{ }^{33}$ after thermal cycling, no grain growth seems to have occurred in CF5 through an Ostwald ripening mechanism. As anticipated, no intergranular phase was formed, since no sintering aids were added to prevent the collapse of the 3D structure upon the burning off of the polyurethane/PVA template. In this respect, the addition of $5 \%$ PVA to the slurry played a crucial role in preventing such collapse. The fact that the material struts in CF5 are not fully dense as in CF may explain the remarkable increase in the observed redox performance.

The 3-DOM cork-templated ceria exhibited an increase in the $\mathrm{H}_{2}$ production rates despite the densification resulting from the high temperature required for sintering $\mathrm{CeO}_{2}$. Therefore, the material activity and cyclical stability were not altered. Alternative processing routes must be envisaged in order to minimise grain growth (for instance, through doping of $\left.\mathrm{CeO}_{2}\right)$ and rendering the material easier to reduce. This requires the development of materials having high surface area based upon an interconnected pore network, which must be retained over many thousands of cycles and hours of operation at temperatures in excess of $1400{ }^{\circ} \mathrm{C}$. As well as improvements in the ecoceramic process, future work will also focus on robocasting ceria structures suitable for solar fuel production. 


\section{Conclusions}

Three $\mathrm{CeO}_{2}$ materials with differing morphologies and microstructures were evaluated for $\mathrm{H}_{2} \mathrm{O}$ splitting under solar thermochemical cycling. After a reduction step at $1400{ }^{\circ} \mathrm{C}$ in inert gas, the total $\mathrm{H}_{2}$ yield of cork-templated ceria was typically around $30 \%$ higher than its ceria foam counterpart. During ceria reduction step, oxygen release occurred at a much slower rate than $\mathrm{H}_{2}$ evolved during the oxidation step. The $\mathrm{H}_{2}$ production rate also increased when decreasing the oxidation temperature while the $\mathrm{H}_{2}$ yield was not significantly affected. In contrast, the $\mathrm{H}_{2}$ yield was mainly dependent on the reduction extent (i.e. the amount of oxygen non-stoichiometry), thus to the reduction temperature. The superior $\mathrm{H}_{2} \mathrm{O}$-splitting activity and noticeable chemical stability of the cork-templated ceria was evidenced. This is attributed to difference in surface availability for the solid-gas reactions. It can also be inferred that surface rather than bulk diffusion of oxygen ions is the rate controlling mechanism. Indeed, the surface area of both materials is less than $1 \mathrm{~m}^{2} \mathrm{~g}^{-1}$ which is a consequence of the high temperature sintering or thermal cycling.

The nature (semi-closed) and cell size $(25 \mu \mathrm{m})$, substantially smaller compared to their CF5 counterparts $(575 \mu \mathrm{m})$, of the cork-templated ceria is presumed to account for the higher specific $\mathrm{H}_{2}$ yields of cork-templated sample compared to foam.

Following our previous work on green aqueous synthesis involving four infiltration steps of the cork precursor, we also explored a single infiltration using acetone, instead of water as the solvent. However, the resulting ceria ecoceramic produced lower $\mathrm{H}_{2}$ yields than the more sustainable, aqueous process. The improved reactivity and performance stability of a novel class of ceria-based materials prepared from cork template was demonstrated during repeated solar-driven $\mathrm{H}_{2} \mathrm{O}$-splitting cycles offering new prospects for green hydrogen production.

\section{Conflicts of interest}

There are no conflicts to declare. 


\section{Acknowledgements}

We thank the PROMES-CNRS Laboratory for providing access to its installations, the financial support of French National Agency for Research (ANR, SUNFUEL project, contract NANR-16-CE06-0010), and of SFERA-III project (Grant Agreement No 823802). National funding provided by FCT, in the frame of the H2CORK project, grant no. PTDC/CTM-ENE/6762/2014 as well as POCI-01-0145-FEDER-016862 is also gratefully acknowledged. RMN was supported by a post-doc research fellowship and FCT grant CEECIND/00335/2017, whereas AIM and PMOS research grants were also funded in the frame of the H2CORK project. Thanks are also due to Amorim Cork Composites, S.A. and Flexipol - Espumas Sintéticas S.A. for donating the cork samples and the PU foams, respectively. RCP wishes to thank FCT grant IF/00681/2015 for supporting this work. This work was developed within the scope of the project CICECO-Aveiro Institute of Materials, UIDB/50011/2020 \& UIDP/50011/2020, financed by national funds through the FCT/MEC and when appropriate co-financed by FEDER under the PT2020 Partnership Agreement. The financial support provided by INIESC - National Research Infrastructure for Concentrated Solar Energy through contract ALT20-03-0145-FEDER-022113 is also thanked. 


\section{References}

1 J.D. Holladay, J. Hu, D.L. King and Y. Wang, Catal. Today, 2009, 139, 244-260.

2 N.V. Gnanapragasam and M.A. Rosen, Biofuels, 2017, 8, 725-745.

3 T. Ogawa, M. Takeuchi and Y. Kajikawa, Sustainability, 2018, 10, 478.

4 M. Wang, Z. Wang, X. Gong and Z. Guo, Renew. Sust. Energy Rev., 2014, 29, 573-588.

5 L. D'Souza, Mater. Renew. Sustain. Energy, 2013, 2, 7.

6 J.E. Miller, A.H. McDaniel and M.D. Allendorf, Adv. Energy Mater., 2014, 4, 1-19.

7 J.R. Scheffe and A. Steinfeld, Mater. Today, 2014, 17, 341-348.

8 S. Abanades, Chem. Eng., 2019, 3, 63.

9 B. Bulfin, J. Vieten, C. Agrafiotis, M. Roeb and C. Sattler, J. Mater. Chem. A, 2017, 5, 18951-18966.

10 R.J. Panlener, R.N. Blumenthal and J.E. Garnier, J. Phys. Chem. Solids, 1975, 36, 1213-1222.

11 L. Wang, M. Al-Mamun, Y. L. Zhong, L. Jiang, P. Liu, Y. Wang, H.G. Yang and H. Zao, Sustain. Energy Fuels, 2017, 1, 1013-1017.

12 T. Nakamura, Sol. Energy, 1977, 19, 467-475.

13 M.D. Allendorf, R.B. Diver, N.P. Siegel and J.E. Miller, Energy \& Fuels, 2008, 22, 41154124.

14 M. Roeb, M. Neises, N. Monnerie, C. Call, H. Simon, C. Sattler, M. Schmücker and R. Pitz-Paal, Materials, 2012, 5, 2015-2054.

15 H. Kaneko, T. Miura, H. Ishihara, S. Taku, T. Yokoyama, H. Nakajima and Y. Tamaura, Energy, 2007, 32, 656-663.

16 H. Kaneko, H. Ishihara, S. Taku, Y. Naganuma, N. Hasegawa and Y. Tamaura, J. Mater. Sci., 2008, 43, 3153-3161.

17 N. V. Skorodumova, S. I. Simak, B. I. Lundqvist, I. A. Abrikosov and B. Johansson, Phys. Rev. Lett., 2002, 89, 166601

18 K. Otsuka, M. Hatano and A. Morikawa, Inor. Chim. Acta, 1985, 109, 193-197.

19 S. Abanades and G. Flamant, Solar Energy, 2006, 80, 1611-1623.

20 N. Knoblauch, H. Simon and M. Schmücker, Solid State Ion., 2017, 301, 43-52.

21 Y. Lu, L. Zhu, C. Agrafiotis, J. Vieten, M. Roeb and C. Sattler, Prog. Energy Combust. Sci., 2019, 75, 100785. 
22 H. L. Tuller and A. S. Nowick, J. Electrochem. Soc., 1979, 126, 209-217.

23 R.C. Pullar, R.M. Novais, A.P.F. Caetano, M.A. Barreiros, S. Abanades and F.A.C. Oliveira, Front. Chem., 2019, 7, Article 601.

24 L. J. Venstrom, N. Petkovich, S. Rudisill, A. Stein and J. H Davidson, J. Sol. Energy Eng., 2012, 134, 011005.

25 K. Ganesan, J. Randrianalisoa and W. Lipiński, J. Heat Transfer, 2013, 135, 122701.

26 D. J. Keene, W. Lipiński and J. H. Davidson, Chem. Eng. Sci., 2014, 111, 231-243.

27 A. Le Gal and S. Abanades, J. Phys. Chem. C, 2012, 116, 13516-13523.

28 D. Arifin and A.W. Weimer, Solar Energy, 2018, 160, 178-185.

29 A. Riaz, M. U. Ali, T. G. Enge, T. Tsuzuki, A. Lowe and W. Lipiński, AAAS Research, 2020, 2020, Article ID 3049534.

30 X. Gao, G. Liu, Y. Zhu, P. Kreider, A. Bayon, T. Gengenbach, T. Lu, Y. Liu, J. Hinkley, W. Lipiński and A. Tricoli, Nano Energy, 2018, 50, 347-358.

31 S. Brendelberger, H. von Storch, B. Bulfin and C. Sattler, Sol. Energy, 2017, 141, 91-102.

32 S. Brendelberger, J. Vieten, M. Roeb and C. Sattler, Int. J. Hydrog. Energy, 2019, 44, 9802-9810.

33 F.A.C. Oliveira, M.A. Barreiros, S. Abanades, A.P.F. Caetano, R.M. Novais and R.C. Pullar, J. $\mathrm{CO}_{2}$ Util., 2018, 26, 552-563.

34 P. Furler, J. Scheffe, D. Marxer, M. Gorbar, A. Bonk, U. Vogt and A. Steinfeld, Phys. Chem. Chem. Phys., 2014, 16, 10503-10511.

35 H. Pereira, Cork: Biology, production and uses. 1st ed., Elsevier Science B.V., Amsterdam, 2007.

36 R.C. Pullar, L. Gil and F.A.C. Oliveira, C. Tecn. Mater., 2016, 28, 23-28.

37 R.M. Novais and R.C. Pullar, J. Eur. Ceram. Soc., 2019, 39, 1287-1296.

38 F.A.C. Oliveira, S. Dias, J. Mascarenhas, J.M.F. Ferreira, S. Olhero and D. Dias, Mater. Sci. Forum, 2004, 455-456, 177-181.

39 M.J. Matos, M.F. Vaz, J.C. Fernandes and F.A.C. Oliveira, Mater. Sci. Forum, 2004, 455456, 163-167.

40 A. Le Gal, S. Abanades and G. Flamant, Energy Fuels, 2011, 25, 4836-4845. 
41 F. Call, M. Roeb, M. Schmücker, H. Bru, D. Curulla-Ferre, C. Sattler and R. Pitz-Paal, Am. J. Analyt. Chem., 2013, 4, 37-45.

42 R.D. Shannon, Acta Cryst., 1976, A 32, 751-767.

43 C. Muhich, J. Phys. Chem. C, 2017, 121, 8052-8059.

44 C. Muhich and A. Steinfeld, J. Mater. Chem. A, 2017, 5, 15578-15590.

45 R. Jacot, R. Moré, R. Michalsky, A. Steinfeld and G.R. Patzke, J. Mater. Chem. A, 2017, 5, 19901-19913.

46 R. Bader, L.J. Venstrom, J.H. Davidson and W. Lipiński, Energy Fuels, 2013, 27, 5533-5544.

47 S. Abanades, A. Le Gal, A. Cordier, G. Peraudeau, G. Flamant and Anne Julbe, J. Mater. Sci., 2010, 45, 4163-4173.

48 W.C. Chueh and S. M. Haile, Phil. Trans. R. Soc. A, 2010, 368, 3269-3294.

49 Q. Meng, C. Lee, T. Ishihara, H. Kaneko and Y. Tamaura, Int. J. Hydrog. Energy, 2011, 36, 13435-12441.

50 A. Le Gal, S. Abanades, N. Bion, T. Le Mercier and V. Harlé, Energy Fuels, 2013, 27, 6068-6078.

51 M. Hoes, C.L. Muhich, R. Jacot, G.R. Patzke and A. Steinfeld, J. Mater. Chem. A, 2017, 5, 19476-19484.

52 S. Li, V. M. Wheeler, P. B. Kreider, R. Bader and W. Lipiński, Energy Fuels, 2018, 32, 10848-10863.

53 P. Furler, J.R. Scheffe and Aldo Steinfeld, Energy Environ. Sci., 2012, 5, 6098-6103.

54 W.C. Chueh, C. Falter, M. Abbott, D. Scipio, P. Furler, S.M. Haile and A. Steinfeld, Science, 2010, 330, 1797-1801.

55 X. Gao, A. Vidal, A. Bayon, R. Bader, J. Hinkley, W. Lipiński and A. Tricoli, J. Mater. Chem. A, 2016, 4, 9614-9624.

56 N.P. Siegel, J.E. Miller, I. Ermanoski, R.B. Diver and E. B. Stechel, Ind. Eng. Chem. Res., 2013, 52, 3276-3286. 